\title{
Telekelik Siloksan Oligomerleri İçeren Poliüretan Esaslı Kaplamaların Sentezi ve Karakterizasyonları
}

\author{
Mehmet Arif Kaya ${ }^{1 *}$ \\ 1 Yalova Üniversitesi, Mühendislik Fakültesi, Polimer Malzeme Mühendisliği Bölümü, Yalova, Türkiye, (ORCID: 0000-0001-9339-3381), marifkaya@yalova.edu.tr
} (International Conference on Design, Research and Development (RDCONF) 2021 - 15-18 December 2021)

(DOI: 10.31590 /ejosat.1040411)

ATIF/REFERENCE: Kaya, M. A. (2021). Telekelik Siloksan Oligomerleri İçeren Poliüretan Esaslı Kaplamaların Sentezi ve Karakterizasyonlar1. Avrupa Bilim ve Teknoloji Dergisi, (32), 367-382.

\section{$\ddot{O} \mathbf{z}$}

Poliüretanlar (PU) diizosiyanat ve diol monomerlerinin reaksiyonu sonucu oluşan üretan bağlarını ana zincirinde barındıran geniş bir polimer ailesidir. Telekelik siloksan oligomerleri (TSO) uç gruplarında çeşitli reaktif fonksiyonel gruplar taşıyan ve bu fonksiyonel gruplar ile oligomerik yapıdaki farklı polimer bloklarıyla kimyasal olarak bağlanarak, molekül ağırlıkları ve ana zincirdeki bileşimlerine bağlı olarak pek çok uygulamada görev alabilecek blok kopolimerlerin eldesine imkân sağlayan eşşiz malzemelerdir. Çalışmada telekelik Polidimetilsiloksan (PDMS) oligomerlerinin kullanımı ile Poliüretan/Polidimetilsiloksan (PU/PDMS) multiblok kopolimerleri sentezlendi, kaplama malzemesi olarak görev yapması hedeflenen PU/PDMS esaslı malzemelerin bu fonksiyonu yerine getirirken sağlaması gereken en temel fonksiyon özellik olan yalıtım, yapışma performansları başta olmak üzere sertlik özellikleri, mekanik ve termal karakteristikleri ile yanma davranışları belirlenerek, gerçekleştirilen incelemeler sonucu yapı-özellik ilişkisi ortaya konarak en uygun bileşimin belirlenmesi sağland.

\section{Synthesis and Characterizations of Polyurethane Based Coatings Containing Telechelic Siloxane Oligomers}

\begin{abstract}
Polyurethanes (PU) are a large family of polymers that have urethane bonds formed as a result of the reaction of diisocyanate and diol monomers in their main chain. Telechelic siloxane oligomers (TSO) are unique materials that have various reactive functional groups at their end groups and can chemically bond from these functional groups with various oligomer blocks, allowing to obtain block copolymers that can be used in many applications depending on their molecular weight and composition. In this study,

Polyurethane/Polydimethylsiloxane (PU/PDMS) multiblock copolymers were synthesized by using telechelic Polydimethylsiloxane (PDMS) oligomers. Basic functional properties such as insulation and adhesion performance of PU/PDMS-based materials intended to serve as coating material were determined. Also hardness, mechanical and thermal characteristics, and combustion behaviors of PU/PDMS based coatings were examined and the optimum composition was determined by revealing the structure-property relationship as a result of the examinations carried out.
\end{abstract}

Keywords: Polyurethane, Polydimethylsiloxane, Telechelic Oligomer, Multiblock copolymer, Coating, Flammability Behavior.

\footnotetext{
*Sorumlu Yazar: marifkaya@yalova.edu.tr
} 


\section{Giriş}

Günümüzde polimerler gündelik hayatta pek çok alanda kullanılmakta ve modern yaşamın kalitesine büyük katk1 sağlamaktadırlar. Sahip oldukları eşsiz özellikler nedeniyle yaygın olarak hayatımıza giren polimerlerin sergilediği yüksek yanıcılı özellikleri yüzleşilmesi gereken en önemli problemlerden biri olarak karşımıza çıkmaktadır.

Bir yangın kolaylıkla başlayarak, yakıt kaynağı tükenene, temas ettiği yayıldığı nesneleri yok edene, yaralanmalara neden olacak ve saniyeler içinde can alacak seviyelere ulaşıncaya kadar hızlı ve tehlikeli şekilde devam edebilmektedir. Ulusal Yangından Korunma Derneği'ne (NFPA) göre, İtfaiye departmanları ABD özelinde her yıl yaklaşık 7 milyar dolarlık doğrudan hasara neden olan 350.000'den fazla ev yapısı yangınına müdahale etmektedirler. Ayrica bu yangınlarda yılda 2.500 'den fazla sivil ölümü ve 12.300 sivilin yaralanmasının kayda geçtiği rapor edilmektedir. Ölümlerin çoğu, duman ve karbon monoksit gibi zehirli veya yanıcı gazların solunmasından kaynaklanırken, yaralanmaların, yangınlardan yayılan ısıya maruz kalmaktan kaynaklandığı bilinmektedir. $\mathrm{Bu}$ olumsuz sonuçlarla karşılaşılmaması amacıyla polimer endüstrileri için büyük ekonomik, sosyolojik ve yasal baskılar olduğu ve polimerlerin yanıcılık özelliklerinin iyileştirilmesi amacıyla gerçekleştirilen çalışmaların temel motivasyonun bu bağlamda gerçekleştirildiği söylenebilir (Horrocks ve Price, 2001).

Polimerlere yönelik hızla artan talepler ve buna bağlı olarak artan yangın tehlikesi polimer yanıcılığı sorununa yönelik belli yaklaşımların oluşmasını sağlamaktadır. $\mathrm{Bu}$ konuya yönelik yaklaşımların temelinde ilk hedefin özellikle organik sistemler düşünüldüğünde, polimerlerin aleve dayanıklı olması değil, “Alev Geciktirici” özellik sergilemesi gerektiği olarak karşımıza çıkmaktadır. İdeal "Alev Geciktirici” özelliğine sahip bir polimerin tutuşmaya ve alev yayılmasına karşı yüksek dirence, düşük yanma hızına, düşük hız ve miktarda duman oluşumuna, düşük yanıcılığa ve toksisiteye sahip olması beklenmektedir (Pearce, 2012).

Polimerlere "Alev Geciktirici” özelliğin kazandırılması için ise "Alev Geciktirici (Flame Retardant-FR)" adı verilen çeşitli katkı maddelerinin kullanıldığı görülmektedir. Yanıcı bir plastik malzeme, alev geciktirici bir katkı maddesinin eklenmesiyle yanmaz hale gelmez. Bununla birlikte, alev geciktirici polimer, modifiye edilmemiş plastiklere kıyasla tutuşmaya daha uzun süre dayanır, yanması daha uzun sürer ve daha az 1s1 üretir (Harper, 2000; Weil ve Levchik, 2009).

Yaygın olarak kullanılan alev geciktirici katkılar dört ana grupta sınıflandırılabilir: aluminyum trioksit, magnezyum hidroksit, amonyum polifosfat ve kırmızı fosforu içeren inorganik bileşikler, klor ve/veya brom içeren halojenli bileşikler, fosfat esterlerini içeren organofosfor bileşikleri ve azot esaslı bileşikler (Kulshreshtha ve Vasile, 2002).

Son yıllarda, başlıca maliyet, sağlık ve yüksek performans perspektifini önceleyerek bahsi geçen bu alev geciktirici katk1 maddelerine yeni alternatiflerin geliştirilmesi üzerinde çalışmaların gerçekleştirildiği görülmektedir. $\mathrm{Bu}$ alternatifler içinde silikon esaslı alev geciktirici (FR) sistemlerle ilgili yeni makalelerin, patentlerin ve ürünlerin sayısı, tamamen halojenlere veya fosfora dayanmayan FR yaklaşımlarına yenilenen ilginin kanıtıdır. Hemen hemen tüm silikon formları alev geciktirici olarak araştırılmalara konu olmaktadır. Siloksanlar, silikalar, e-ISSN: 2148-2683 organosilanlar; silseskioksanlar ve silikatlar başta olmak üzere silikon esaslı FR araştırmalarında fonksiyonel sonlu gruplara sahip olan telekelik siloksanlar polimer ana zincirine dahil olarak, polimer matrisine eriyik karıştırma yöntemi ile dağıtılarak dahil edilen alternatiflere kıyasla uyumluluk, kalıcılık ve sergiledikleri yüksek performans ile öne çıkmaktadırlar (Grand ve Wilkie, 2000).

Poliüretanlar (PU) üretan (-NH-COO-) bağları içeren genellikle bir diol ve diizosiyanatın reaksiyonundan elde edilen polimerlerdir. Çeşitli glikoller veya diaminler kullanılarak dallanmış ve/veya çapraz bağlı termoplastik veya termoset karakterde poliüretan üretimi mümkündür. Otto Bayer 1937 y1lında ilk kez diizosiyanatlarla poliolleri reaksiyona sokarak poliüretan sentezini gerçekleştirmiştir. Poliüretanlar çok farklı başlangıç maddelerinden çok farklı yapılarda sentez edilebildiklerinden ürünlerin özellikleri de beklendiği gibi birbirinden çok farklıdır. Diğer polimerlerde olduğu gibi molekül ağırlığı ve dağılımı yanı sıra moleküller arası kuvvetler, zincir esnekliği ve dayanıklılığı, kristalizasyon ve çapraz bağlanma vb. gibi özellikler poliüretanlarda da sonuç ürün performansını belirler (Gooch, 2007; Herman, 1964; Parker,2002; Martin, 2010).

Farklı tip başlangıç maddelerinin kullanımı ile Poliüretanlar elastomerlerden fiber imalatına, kaplamalardan köpük imalatına belki de diğer polimerlere kıyasla en geniş skalada kullanım imkânı bulabilmektedir. Poliüretanların yüksek kimyasal direnci, iyi mekanik mukavemet gibi avantaj sağlayan özelliklerinin yanında en bilinen dezavantajı sahip olduğu düşük Sınırlayıcı Oksijen İndeks (LOI) değerleri ve buna bağlı olarak da kolay yanabilmeleridir (Nyilas, 1971).

Silikonlar $\left(\mathrm{R}_{\mathrm{m}} \mathrm{Si}(\mathrm{O})_{4-\mathrm{m} / 2}\right)(\mathrm{m}=1-3, \mathrm{n} \geq 2, \mathrm{R}=$ Alkil vb. fonksiyonel bir grup) formülüne sahip önemli bir polimer ailesidir. Polidimetilsiloksanlar (PDMS) bu ailenin en yaygın olarak kullanılan tipidir.

Silikonlar Şekil 1.1'de verilen genel formülle tanımlanan, silisyum-oksijen bağından oluşmuş bir ana zincir ve buna bağlı alifatik veya aromatik, çeşitli fonksiyonel gruplar veya elementler içerebilen yan (R: alkil gruplan) ve uç gruplar (R': alkil gruplan) taşıyan çok farklı özelliklerde çok geniş bir polimer ailesidir. Burada " $n$ ” tekrarlanan birim sayısını gösterir. R ve R' aynı tür alkil grubu olabilecekleri gibi farklı da olabilirler (Pişkin, 2000).<smiles>[R][Si]([R])([R])[R][Si]([R])([R])O[Si]([R])([R])[R]</smiles>

Şekil 1.1 Silikonların genel yapısı.

Polidimetilsiloksan içeren kopolimerlerinin üzerine yürütülen çalışmaların, polidimetilsiloksan esaslı elastomerlerin istenilen mekanik özellikleri sağlayamaması nedeniyle başlatıldığ 1 söylenebilir. Bilindiği gibi pek çok sıra dışı özelliklerinde rağmen polidimetilsiloksanlar mekanik özellikler açısından oldukça zayıf bir görünüm sergilerler. Yüksek molekül ağırlıklarında bile polidimetilsiloksanlar zayıf elastomer özellikleri ve akma eğilimi gösterirler. $\mathrm{Bu}$ durumun önüne geçmek için polidimetilsiloksanlar uygun ajanlar ile kimyasal olarak çapraz bağlanırlar. $\mathrm{Bu}$ işleme rağmen polidimetilsiloksanlar hala düşük gerilme, yırtılma ve uzama 368 
değerlerine sahiptirler. Gerilim uygulandığında polidimetilsiloksanların sahip oldukları yüksek mobilite, oda sıcaklığında kılcal çatlakların oluşumuna sebep olur.

Polidimetilsiloksan ana zincirinin çeşitli sübstitüentlerle (düşük seviyelerde) modifikasyonu mekanik özelliklerde bir iyileşme sağlasa da bu arzu edilen nitelikte olamamaktadır. Pek çok ticari uygulamada polidimetilsiloksanlara çapraz bağlanma uygulanırken, aynı zamanda (ağırlıkça \%40-50 oranında) yüksek yüzey alanına, düşük tane boyutuna sahip silika ile kompozit haline getirilir. $\mathrm{Bu}$ tip dolguların kullanılması ile mekanik özellikler ciddi oranda iyileşir ancak bu kompozit yapıda gerçekleştirilen çapraz bağlama işleminde de aşılması gereken problemler bulunmaktadır.

Kauçuksu polimerlerin zayıf mekanik özelliklerinin iyileştirilmesi için çapraz bağlanma haricinde etkin ve önemli bir yol daha vardır: blok kopolimerler. $A B$ veya $A B A$ şeklinde blok kopolimerler veya $(\mathrm{AB}) \mathrm{n}$ şeklinde multiblok kopolimerlerin kontrollü sentezi ile yumuşak, kauçuksu bileşen kimyasal olarak camsı veya kristal yapıdaki bileşene bağlanır. $\mathrm{Bu}$ yaklaşım polimer kimyasında oldukça iyi bilinen ve kullanılan bir yöntemdir. Ürün bileşenlerin büyüklüğüne, oranına ve türüne bağlı olarak termoplastik karakterden termoplastik elastomer karaktere geniş bir aralıkta elde edilebilir. Bu sistemler genelde iki faz morfolojisi sergilerler, sert kısımlar kauçuk faz içinde fiziksel olarak çapraz bağlar ve/veya dolgu vazifesi görürler. Daha da önemlisi bu kopolimerler çapraz bağlı yapıda olmadıklarından eriyik veya çözeltiden tekrar tekrar şekillendirilebilirler.

Polidimetilsiloksan içeren kopolimerlerinin sentezinde, başlangıç maddeleri olarak sert, camsı özellik gösteren bir bileşen ile kauçuksu özellikler gösteren polidimetilsiloksan bileşen görev yapmaktadır. $\mathrm{Bu}$ bileşenleri daha yakından incelersek polidimetilsiloksan bloğunun uç gruplarında reaktif bir fonksiyonel grup içerdiği görülebilir. İkinci bileşen olan sert, camsı blok ise polidimetilsiloksanın taşıdığı uç gruplar ile reaksiyon verebilecek uygun fonksiyonel gruplara sahip ve genelde yüksek performanslı mühendislik polimerleridir. Uç gruplarında taşıdıkları reaktif fonksiyonel gruplar nedeniyle telekelik oligomerler olarak adlandırılan bu bloklar uygun koşullar altında birbirlerine kimyasal olarak bağlanarak kopolimerleri oluştururlar.

Polimer kimyasında fonksiyonel grup sonlu reaktif oligomerlerin önemi çok iyi bilinmektedir. Farklı organik fonksiyonel reaktif gruplar ve oligomer ana zincir seçimindeki çeşitlilik çok geniş bir aralıkta blok, multiblok ve graft yapıda kopolimerlerin sentezine ve matrislerin modifikasyonuna imkân sağlamaktadır. Şimdiye kadar en yaygın olarak kullanılan reaktif uç gruplar hidroksil, amin, epoksi ve karboksil fonksiyonlu gruplarıdır. Pek çok endüstriyel uygulamalara bakıldığında ana zincir olarak poli(alkilen oksit)ler, polyesterler, polibütadien akrilonitril ve bisfenol A esaslı epoksi reçinelerin görev yaptığ 1 görülebilir. Son zamanlarda fenol, amin, asetilen, ve bismaleimid uç gruplara sahip poliimidler, polisülfonlar ve poliarilen eterler gibi çeşitli termal dayanıma sahip aromatik ana zincirlere sahip polimerler üzerinde yaygın bir şekilde çalışmalar yürütülmektedir.

Reaktif uç gruplara sahip siloksan oligomerler 1940'l1 yıllarında başındaki keşiflerinden bu yana yaygın olarak "silikon kauçuklar"1n eldesinde görev almaktadırlar. Günümüzde poliüretan köpük formülasyonlarında yer alan polidimetilsiloksan-poli(alkilen oksit) kopolimeri esaslı yüzey aktif maddelerin ise 1950'li yılların ortalarında üretime geçtiği bilinmektedir.

Özel uygulamalar için, $\alpha, \omega$-organofonksiyonel uç gruplu siloksanlar en önemli başlangıç maddesi veya ara ürün olarak günümüzde kabul görmektedir. Karbon-fonksiyonel organik gruplara sahip silikonların kullanımının önümüzdeki yıllarda önemli gelişmelere sahne olacağı ve yine bu kullanımın organosilikon kimyası ve organik kimya arasında bir köprü vazifesi göreceği öngörüsünün haklılığı kanıtlandığ ç̧alışmalar incelendiğinde görülebilir (Yilgör ve McGrath, 1988; Kazama, Tezuka ve Imai, 1989; Zhu, Feng ve Zhang, 2003; Tezuka, Kazama ve lmai, 1991; Kozakiewicz, 1996).

Poliüretan esaslı kaplamaların yüzleşmesi gereken en önemli dezavantajı kolay yanabilmesidir. Çalışmamızda bu olumsuz özelliğin iyileştirilmesi, özellikle yapı sektöründe zemin kaplama malzemesi başta olmak üzere metal ve ahşap yüzeylere de uygulanabilecek nitelikte yanma dayanımı iyileştirilmiş poliüretan esaslı kaplamaların sentezi ve özelliklerinin belirlenmesi hedeflenmektedir. Bu amaçla çalışmada telekelik Polidimetilsiloksan (PDMS) oligomerlerinin kullanımı ile Poliüretan/ Polidimetilsiloksan (PU/PDMS) multiblok kopolimerleri sentezlendi. Bir kaplama malzemesi olarak görev yapması hedeflenen PU/PDMS esaslı malzemelerin bu fonksiyonu yerine getirirken sağlaması gereken en temel fonksiyon özelliği olan yalıtım performansları da belirlenerek, gerçekleştirilen incelemeler sonucu yapı-özellik ilişkisi ortaya konarak en uygun bileşimin belirlenmesi sağlandı.

\section{Materyal ve Metot}

\subsection{Materyaller}

Poliüretan esaslı tüm kaplamaların sentezlerinde diizosiyanat monomerleri olarak aromatik yapıdaki metilendifenil diizosiyanat (MDI) veya alifatik yapıdaki İzoforondiizosiyanat (IPDI) monomeri, poliol olarak $2000 \mathrm{~g} / \mathrm{mol}$ molekül ağırlığındaki polipropilen glikol (PPG) veya Tegomer® H-Si 2315 kodlu $\alpha, \omega-$ hidroksi alkil telekelik polidimetilsiloksan oligomeri (PDMS), (özellikleri Tablo 2.1 de verilmektedir) zincir uzatıcı olarak monopropilen glikol (MPG) kullanıldı. MDI, IPDI, PPG ve MPG PÜRIN Poliüretan firmasından, PDMS Evonik firmasından temin edildi. Diizosiyanat ve tüm polioller kuru Argon atmosferinde tutuldu ve polimerizasyon reaksiyonları öncesinde vakum etüvünde uygun sicaklıklarda 24 saat süreyle tutularak kurutuldu.

Tablo 2.1 Tegomer ${ }^{\circledR} H$-Si 2315 Kodlu A,S-Hidroksi Alkil Telekelik PDMS Oligomerinin Özellikleri.

\begin{tabular}{l|r}
\hline$\ddot{O}_{\text {zellik }}$ & \\
\hline Asit Sayı1 & $0,5 \mathrm{mg} \mathrm{KOH} / \mathrm{g}$ \\
\hline Hidroksil Sayıs1 & $48 \mathrm{mg} \mathrm{KOH} / \mathrm{g}$ \\
\hline Viskozite & $90 \mathrm{mPa} \mathrm{s}$ \\
\hline Form & $\mathrm{S} 1 \mathrm{v} 1$ \\
\hline Molekül Ağırlığ1 & $2315 \mathrm{~g} / \mathrm{mol}$ \\
\hline
\end{tabular}

Polimerizasyon reaksiyonlarında katalizör olarak Dibütiltin dilaurat (DBTDL), polimerizasyon reaksiyonlarında reaksiyon ortamının seyreltilmesi, uygun viskozitenin sağlanması için ve çözeltiden dökme yöntemi ile poliüretan kaplamalarının hazırlanmasında çözücü olarak tolüen, ksilen, dimetilformamid (DMF), dimetilasetamid (DMAc) ve tetrahidrofuran (THF), poliüretan numuneleri için ilave saflaştırma yapılmak istendiğinde çöz-çöktür yönteminde non-solvent olarak metil alkol $(\mathrm{MeOH})$ ve etil alkol $(\mathrm{EtOH})$ kullanıldı. Analitik saflıkta 
olan tüm katalizör ve çözücüler Sigma Aldrich firmasından temin edildi ve ilave bir saflaştırma uygulanmaksızın temin edildikleri gibi kullanıldı.

\subsection{Poliüretan Esaslı Kaplamaların Sentezi}

Poliüretan esaslı kaplamaların hazırlanması için gerçekleştirilen tüm polimerizasyon reaksiyonları $500 \mathrm{~mL}$ lik 3 boyunlu balonlarda, kuru Argon atmosferi ve mekanik karıştırıcı yardımıyla sağlanan $200 \mathrm{rpm}$ sabit karıştırma hızı altında gerçekleştirildi. Balona öncelikle belirlenen miktarlarda homopolimerler için uygun poliol veya siloksan içeren blok kopolimerler için $\alpha, \omega$-hidroksi alkil telekelik PDMS oligomeri, zincir uzatıcı ve katalizör konuldu, tüm reaksiyonlarda eşit katı madde miktarına erişilecek şekilde uygun miktardaki çözücü ortama ilave edildi. Hedeflenen sıcaklık değerine ulaşıldığında reaksiyon ortamına belirlenen miktardaki diizosiyanat monomeri azalan miktarlarda kısım kısım şırınga yardımıyla damla damla ilave edildi. Diizosiyanat monomerinin ilavesi ilk olarak belirlenen miktarının \%50 si, 2. aşamada belirlenen miktarının $\% 25 \mathrm{i}, 3$. aşamada belirlenen miktarının \%15 i, son olarak da belirlenen miktarının \%10 u olacak şekilde toplamda 4 kısım halinde ilave edildi. Reaksiyonun ilerlemesi ortamdan alınan örneklerin FT-IR spektroskopi yöntemi ile incelenmesi ile takip edildi. Örneklerde izosiyanat fonksiyonel grubuna ait spesifik pikin kaybolduğu an reaksiyon sonlandırıldı.

\subsubsection{Poliüretan Homopolimerlerinin Sentezi}

Çalışmanın temel amacı $\alpha, \omega$-hidroksi alkil telekelik PDMS oligomerinin poliüretan esaslı kaplamaların yapısına girmesinin başta yanma davranışı olmak üzere diğer kaplama özellikleri üzerine etkisinin incelenmesidir. Bu amaca yönelik özellikler üzerindeki değişimin kıyaslamalı incelenebilmesi için öncelikle $\alpha, \omega$-hidroksi alkil telekelik PDMS oligomeri içermeyen homopolimer yapıdaki poliüretan kaplamaların hazırlanması ve bu kaplamaların özelliklerinin belirlenmesi hedeflendi.<smiles></smiles>

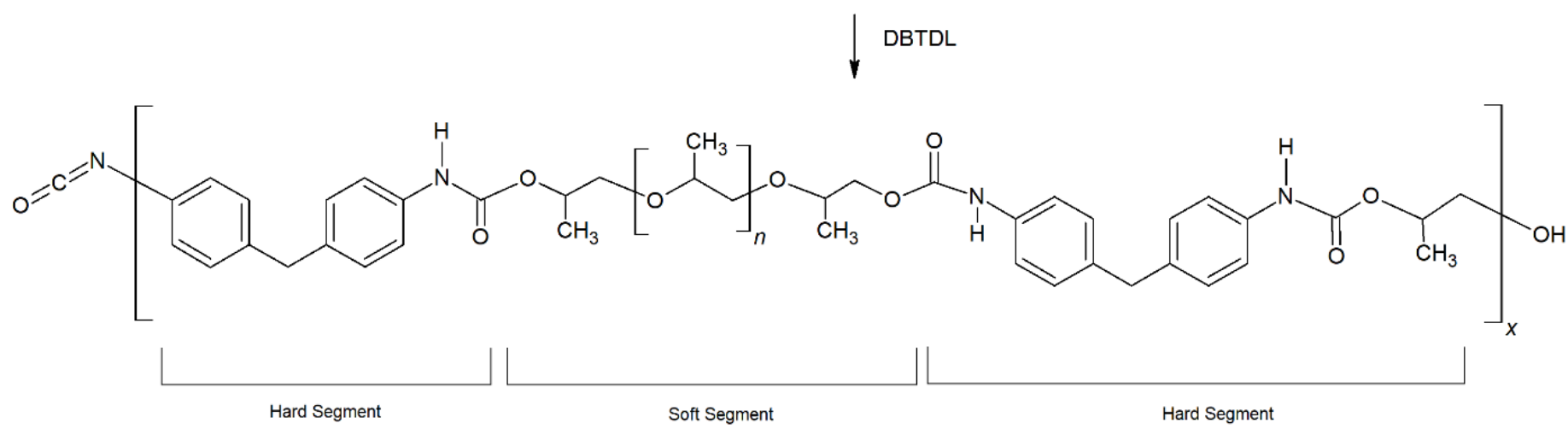

Şekil 2.1 MDI Monomeri Esaslı Homopolimer Yapıdaki Poliüretanların Sentezinin Şematik Gösterimi.

Bu amaçla farklı yapılardaki diizosiyanat monomerlerinden Metilendifenil diizosiyanat (MDI) ve İzoforondiizosiyanat (IPDI) bileşikleri kullanıldı. Poliol olarak ise gerçekleştirilen ön denemeler neticesinde daha uygun sonuçlar sergileyen 2000 g/mol molekül ağırlığına sahip polipropilen glikol (PPG 2000) tercih edildi. Dimetilformamid (DMF) çözücüsü, Dibütiltin dilaurat (DBTDL) katalizörlüğünde gerçekleştirilen polimerizasyon reaksiyonlarında zincir uzatıcı olarak Monopropilen glikol (MPG) devreye alındı. Reaksiyonlarda sert (hard) segment ve yumuşak (soft) segment oranları zincir uzatıcı ile poliolün mol oranları değiştirilerek sağlandı. Farklı sert/yumuşak segment oranlarına sahip kaplamalar hazırlanarak bu parametrenin kaplama özellikleri üzerine olan etkisi ortaya konulmaya çalışıldı. Homopolimer yapıdaki poliüretan kaplamaların hazırlanmasında öncelikle MDI monomeri kullanıldı. MDI monomeri kullanılarak gerçekleştirilen polimerizasyon reaksiyonlarının şematik genel gösterimi Şekil 2.1 de verilmektedir.

MDI esaslı homopolimer yapıdaki poliüretan kaplamaların hazırlanmasından sonra, IPDI esaslı homopolimer yapıdaki poliüretan kaplamaların hazırlanması aşamasına geçildi. IPDI monomeri kullanılarak gerçekleştirilen polimerizasyon reaksiyonlarının şematik genel gösterimi Şekil 2.2 de verilmektedir. MDI ve IPDI esaslı homopolimer yapıdaki poliüretan kaplamalarda zincir uzatıcı:poliol oranları dolayısıyla sert:yumuşak segmentlerin oranlarının değiştirildiği örneklerin hazırlanmasında esas alınan değerler ve ilgili örnek kodları Tablo 2.2 de verilmektedir.

\subsubsection{PDMS İçeren Blok Kopolimerlerin Sentezi}

Çalışmamızın bu aşamasında $\alpha, \omega$-hidroksi alkil telekelik PDMS oligomeri içeren poliüretan esaslı kaplamaların hazırlanması hedeflendi.

$\mathrm{Bu}$ hedefe yönelik olarak farklı yapılardaki diizosiyanat monomerlerinden Metilendifenil diizosiyanat (MDI) ve İzoforondiizosiyanat (IPDI) bileşikleri kullanıldı. Poliol olarak ise homopolimer yapıdaki poliüretan kaplamaların hazırlanmasında kullanılan $2000 \mathrm{~g} / \mathrm{mol}$ molekül ağırlığına sahip polipropilen glikole (PPG 2000) molekül ağırlığı olarak en yakın olan ticari alternatif olan molekül ağırlığ $2315 \mathrm{~g} / \mathrm{mol}$ olan $\alpha, \omega$ - 
hidroksi alkil telekelik PDMS oligomeri (Tegomer ${ }^{\circledR}$ H-Si 2315) tercih edildi. Çözücü olarak gerçekleştirilen ön denemelerden en olumlu sonucu veren hacimce 3:1 oranındaki THF:DMAc çözücü karışımı içinde Dibütiltin dilaurat (DBTDL) katalizörlüğünde gerçekleştirilen polimerizasyon reaksiyonlarında zincir uzatıcı olarak Monopropilen glikol (MPG) devreye alınd. Reaksiyonlarda sert (hard) segment ve yumuşak (soft) segment oranları zincir uzatıcı ile poliolün mol oranları değiştirilerek sağlandı. Farklı sert/yumuşak segment oranlarına sahip kaplamalar hazırlanarak bu parametrenin kaplama özellikleri üzerine olan etkisi ortaya konulmaya çalışıldı.
MDI ve IPDI monomeri kullanılarak gerçekleştirilen kopolimerizasyon reaksiyonlarının şematik genel gösterimi sırasıyla Şekil 2.3 ve Şekil 2.4. de verilmektedir. MDI ve IPDI esasl PU/PDMS blok kopolimer kaplamalarda zincir uzatıcı:poliol oranları dolayısıyla sert:yumuşak segmentlerin oranlarının değiştirildiği örneklerin hazırlanmasında esas alınan değerler ve ilgili örnek kodları ise sırasıyla Tablo 2.3 de verilmektedir.

Tablo 2.2 MDI ve IPDI Esaslı Hazırlanan Homopolimer Yapıdaki Poliüretan Kaplamaların Bileşim Özellikleri.

\begin{tabular}{l|c|c|c|c|c|c|c|c|c}
\hline $\begin{array}{c}\text { Polimer } \\
\text { Kodu }\end{array}$ & $\begin{array}{c}\text { İzosiyanat } \\
\text { Tipi ve } \\
\text { Miktar1 } \\
(\mathrm{mmol})\end{array}$ & $\begin{array}{c}\text { Poliol } \\
(\text { PPG2000) } \\
\text { Miktar1 } \\
(\mathrm{mmol})\end{array}$ & $\begin{array}{c}\text { Zincir } \\
\text { Uzat1c1 } \\
(\mathrm{MPG}) \\
\text { Miktar1 } \\
(\mathrm{mmol})\end{array}$ & $\begin{array}{c}\text { Katalizör } \\
(\mathrm{DBTDL}) \\
\text { Miktar1 } \\
(\mathrm{mmol})\end{array}$ & $\begin{array}{c}\text { Çözücü } \\
(\mathrm{DMF}) \\
\text { Miktar1 } \\
(\mathrm{mL})\end{array}$ & $\begin{array}{c}\text { NCO:OH } \\
\text { Oran1 } \\
(\mathrm{mol})\end{array}$ & $\begin{array}{c}\text { Zincir } \\
\text { Uzatıc1:Poliol } \\
\text { Oran1 } \\
(\mathrm{mol})\end{array}$ & $\begin{array}{c}\text { Kat1 } \\
\text { Madde } \\
\text { Miktar1 } \\
(\% \mathrm{w})\end{array}$ & $\begin{array}{c}\text { Yumuşak } \\
\text { Segment } \\
\text { Oran1 } \\
(\% \mathrm{~mol})\end{array}$ \\
\hline MP0 & MDI 30 & 30 & 0 & 1 & 110 & $1: 1$ & $0: 1$ & 65 & 50 \\
\hline MP1 & MDI 50 & 25 & 25 & 2 & 105 & $1: 1$ & $1: 1$ & 65 & 20 \\
\hline MP3 & MDI 80 & 20 & 60 & 3,2 & 105 & $1: 1$ & $3: 1$ & 65 & 12,5 \\
\hline MP5 & MDI 102 & 17 & 85 & 4 & 108 & $1: 1$ & $5: 1$ & 65 & 8,3 \\
\hline IP0 & IPDI 30 & 30 & 0 & 1 & 108 & $1: 1$ & $0: 1$ & 65 & 50 \\
\hline IP1 & IPDI 50 & 25 & 25 & 2 & 102 & $1: 1$ & $1: 1$ & 65 & 20 \\
\hline IP3 & IPDI 80 & 20 & 60 & 3,2 & 100 & $1: 1$ & $3: 1$ & 65 & 12,5 \\
\hline IP5 & IPDI 102 & 17 & 85 & 4 & 102 & $1: 1$ & $5: 1$ & 65 & 8,3 \\
\hline
\end{tabular}

\subsubsection{Kaplamaların Hazırlanmast}

MDI ve IPDI monomerleri kullanılarak hazırlanan homopolimer ve blok kopolimer yapıdaki poliüretan kaplamalara ait polimerizasyon reaksiyonların bitiminde örnekler iç yüzeyi silikon kaplı kalıplara alınarak kurutuldu. Daha sonra homojen kalinlıkta uygun filmlerin hazırlanması için poliüretan kaplamalar tekrardan uygun çözücülerde çözüldü. Bu işlem için homopolimer yapıdaki poliüretan örnekleri için DMF çözücüsü, blok kopolimer yapıdaki poliüretan örnekleri için THF:DMAc çözücü karışımı kullanıldı, çözeltiler $250 \mathrm{~mL}$ lik beherlerde oda sıcaklığında manyet yardımıyla karıştırılarak ve çözeltilerin katı madde miktarı \%20 oranında olacak şekilde hazırland1. Hazırlanan çözeltiler film aplikatörü yardımıyla ıslak kalınlıkları $120 \mu \mathrm{m}$ olacak şekilde silikon yüzeylere yayıldı. Uygun kurutma işlemleri sonrasında ele geçen filmler karakterizasyon işlemlerinde kullanıldı.<smiles>CC1(C)CC(N=C=O)CC(C)(CN=C=O)C1</smiles>

IPDI<smiles>CCC(C)(CC(C)OC(C)(C)CC(C)O)OC(C)CO[I+]</smiles>

PPG

MPG DBTDL

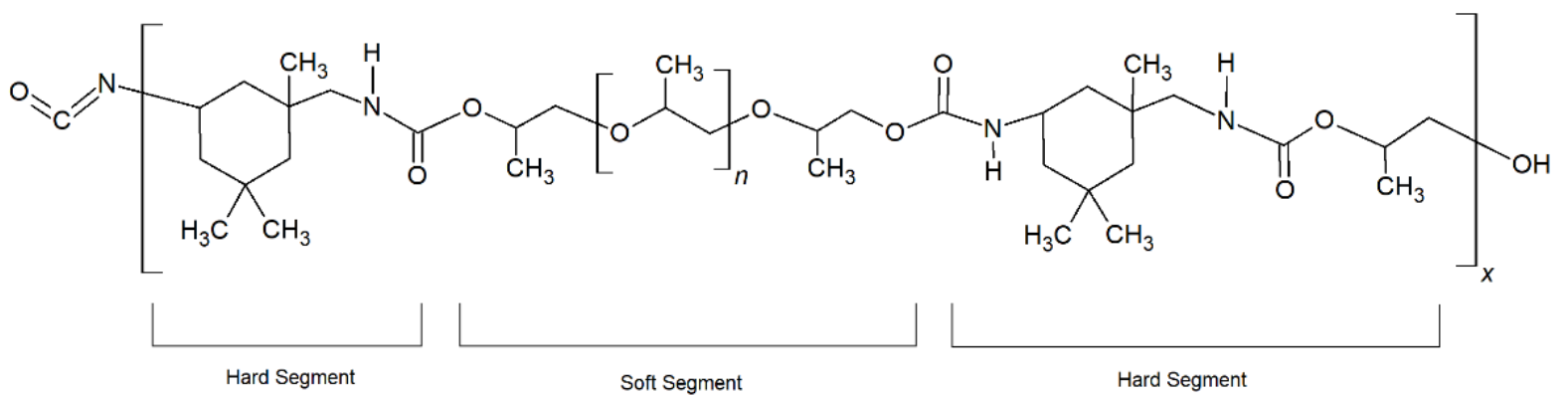

Şekil 2.2 IPDI Monomeri Esaslı Homopolimer Yapıdaki Poliüretanların Sentezinin Şematik Gösterimi. 


\subsubsection{Saflaştırma ve Ekstraksiyon İşlemi}

Elde edilen film örnekleri safsılılklardan kurtulmak amacıyla Soxhlet aparatı yardımıyla ekstraksiyon işlemine tabi tutuldu. Çözücü olarak monomerik olarak ortamda kalabilecek tüm safsızlıkları çözebilecek metanol nonsolventi kullanıldı. İşlem 8 saat süre devam ettirildi, işlem sonrasinda örnekler vakum etüvünde $65^{\circ} \mathrm{C}$ de 24 saat süre ile kurutuldu.<smiles>CC(O)CO</smiles>

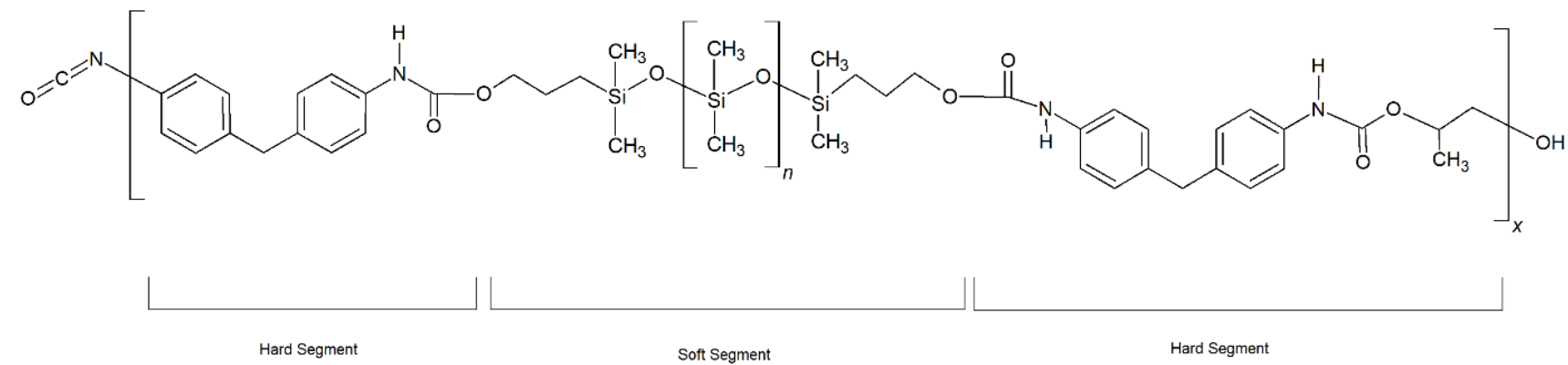

Şekil 2.3 MDI Monomeri Esaslı PU/PDMS Blok Kopolimerlerin Sentezinin Şematik Gösterimi.<smiles>CC(O)CO</smiles>
$\downarrow$ DBTDL

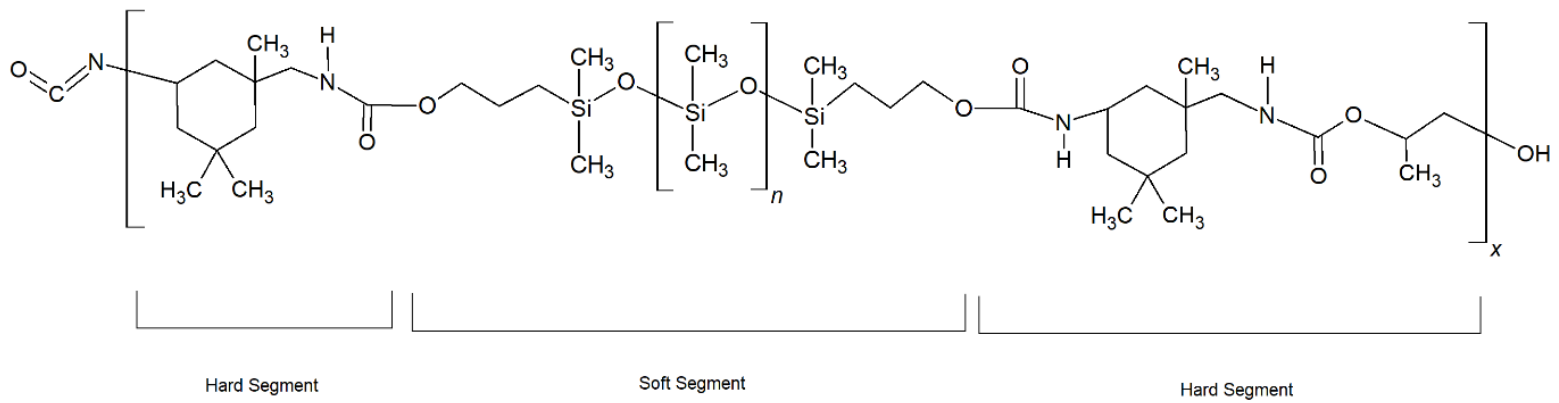

Şekil 2.4 IPDI Monomeri Esaslı PU/PDMS Blok Kopolimerlerin Sentezinin Şematik Gösterimi.

\subsection{Karakterizasyonlar}

\subsubsection{Kaplamaların Yaptsal Karakterizasyonu}

Polimerizasyon reaksiyonlarının ilerlemesi, poliüretan örneklerinin kimyasal yapılarının belirlenmesi ve doğrulanması maksadıyla FT-IR spektroskopisinden yararlanıldı. Film halindeki poliüretan örneklerinin FT-IR spektrumları Perkin
Elmer Spectrum One cihazından ATR aparatı kullanılarak 650$4000 \mathrm{~cm}^{-1}$ aralığında $4 \mathrm{kez}$ tarama yapılarak alındı.

\subsubsection{Kaplamaların Mekanik Özelliklerinin Belirlenmesi}

Poliüretan örneklerinin mekanik özellikleri $1 \mathrm{kN}$ lık load cell'e sahip Zwick marka üniversal test cihazında ASTM D 638 standardına uygun olarak $50 \mathrm{~mm} /$ dak. çekme hızında $20 \times 100$ 
mm ebatlarındaki film örnekleri kullanılarak tespit edildi. Tüm testler oda sıcaklığında gerçekleştirildi. Her bir test 5 adet standarda uygun olarak hazırlanan numuneler üzerinde gerçekleştirildi. Örneklerden elde edilen değerlerin ortalaması sonuç olarak verildi.

\subsubsection{Kaplamaların Sertlik Özelliklerinin Belirlenmesi}

Poliüretan örneklerinin sertlik değerleri ASTM D 2240 standardına göre Zwick marka sertlik cihazı ile gerçekleştirildi, numunenin farklı noktalarından toplam 10 adet gerçekleştirilen ölçümler Shore A tipi değerleri olarak kayıt altına alındı.

\subsubsection{Kaplamalarin Belirlenmesi \\ Termal Dayanım \\ Özelliklerinin}

Poliüretan örneklerinin termal dayanım özellikleri Seiko SII TG/DTA 6300 marka termogravimetrik analiz cihazı kullanılarak belirlendi. Ölçümler azot atmosferinde $10^{\circ} \mathrm{K} /$ dak. 1sıtma hızı ile oda sıcaklığından $750{ }^{\circ} \mathrm{C}$ ye kadar işlem devam edecek şekilde alınd1.

Tablo 2.3 MDI ve IPDI Esaslı Hazırlanan PU/PDMS Blok Kopolimerlerin Bileşim Özellikleri.

\begin{tabular}{|c|c|c|c|c|c|c|c|c|c|}
\hline $\begin{array}{l}\text { Polimer } \\
\text { Kodu }\end{array}$ & $\begin{array}{l}\text { İzosiyanat } \\
\text { Tipi ve } \\
\text { Miktar1 } \\
\text { (mmol) }\end{array}$ & $\begin{array}{c}\text { Poliol } \\
\text { (Tegomer }{ }^{\circledR} \\
\text { H-Si 2315) } \\
\text { Miktar1 } \\
\text { (mmol) }\end{array}$ & $\begin{array}{l}\text { Zincir } \\
\text { Uzatıc1 } \\
\text { (MPG) } \\
\text { Miktarı } \\
\text { (mmol) }\end{array}$ & $\begin{array}{c}\text { Katalizör } \\
\text { (DBTDL) } \\
\text { Miktarı } \\
(\mathrm{mmol})\end{array}$ & $\begin{array}{c}\text { 3:1 (v:v) } \\
\text { oranındaki } \\
\text { THF:DMAc } \\
\text { Çözücü } \\
\text { karışım } \\
\text { Miktarı } \\
\text { (mL) }\end{array}$ & $\begin{array}{c}\mathrm{NCO}: \mathrm{OH} \\
\text { Oranı } \\
(\mathrm{mol})\end{array}$ & $\begin{array}{c}\text { Zincir } \\
\text { Uzatıc1:Poliol } \\
\text { Oranı } \\
(\mathrm{mol})\end{array}$ & $\begin{array}{l}\text { Kat1 } \\
\text { Madde } \\
\text { Miktar1 } \\
(\% \mathrm{w})\end{array}$ & $\begin{array}{c}\text { Yumuşak } \\
\text { Segment } \\
\text { Oranı } \\
(\% \mathrm{~mol})\end{array}$ \\
\hline MS0 & MDI 30 & 30 & 0 & 1 & 132 & $1: 1$ & $0: 1$ & 65 & 50 \\
\hline MS1 & MDI 50 & 25 & 25 & 2 & 124 & $1: 1$ & $1: 1$ & 65 & 20 \\
\hline MS3 & MDI 80 & 20 & 60 & 3,2 & 120 & $1: 1$ & $3: 1$ & 65 & 12,5 \\
\hline MS5 & MDI 102 & 17 & 85 & 4 & 120 & $1: 1$ & $5: 1$ & 65 & 8,3 \\
\hline IS0 & IPDI 30 & 30 & 0 & 1 & 128 & $1: 1$ & $0: 1$ & 65 & 50 \\
\hline IS1 & IPDI 50 & 25 & 25 & 2 & 120 & $1: 1$ & $1: 1$ & 65 & 20 \\
\hline IS3 & IPDI 80 & 20 & 60 & 3,2 & 116 & $1: 1$ & $3: 1$ & 65 & 12,5 \\
\hline IS5 & IPDI 102 & 17 & 85 & 4 & 116 & $1: 1$ & $5: 1$ & 65 & 8,3 \\
\hline
\end{tabular}

\subsubsection{Kaplamaların Yapışma Kuvvetinin Belirlenmesi}

Poliüretan örneklerinin yapışma kuvvet özellikleri ASTM D 3359 standardına göre Çapraz Kesim (Cross Cut) Adhezyon testi ile tespit edildi. Uygun çözücülerin kullanımı ile hazırlanan poliüretan örneklerinin çözeltileri önceden aseton ile temizlenmiş alüminyum plakalara ve yüzeyi fırça ile tozdan arındırılmış beton örnekler üzerine film aplikatörü ile tatbik edildi. Uygun kuruma sürelerinden sonra testler gerçekleştirildi.

\subsubsection{Kaplamaların Su Yalıtım Özelliğinin Belirlenmesi}

Poliüretan örneklerinin su yalıtım özellikleri BS EN 1928 standardı Metot A'ya göre belirlendi. Ölçümler oda sıcaklığında 24 saat süre ile $500 \mathrm{~mm}$ ve $750 \mathrm{~mm}$ su sütunu yüksekliklerindeki basınçlara karşı gerçekleştirildi.

\subsubsection{Kaplamaların Yanma Davranışının Belirlenmesi}

Poliüretan örneklerinin yanma davranışları UL 94 standardına göre, yatay yanma hızları ise ASTM D 635 standardına göre belirlendi. Uygun çözücülerin kullanımı ile hazırlanan poliüretan örneklerinin çözeltileri silikon yüzeylerde film aplikatörü kullanılarak tatbik edildi eşit kalınlıkta olan film numuneleri üzerinde testler gerçekleştirildi.

\section{Araştırma Sonuçları ve Tartışma}

\subsection{Kaplamaların Yapısal Karakterizasyonu}

Sentezlenen poliüretan kaplamaların film oluşturma, genel görünüm ile ilgili özellikleri Tablo 3.1 de verilmektedir.
Poliüretan kaplamaların gözle muayenesinden elde edilen verilen özelliklere bakıldığında, molce $\% 50$ oranında yüksek yumuşak segmente (molce yüksek oranda poliol veya $\alpha, \omega$-hidroksi alkil telekelik PDMS oligomeri içeren) sahip örneklerin beklenildiği gibi film oluşturma özelliklerinin zayıf olduğu, ele geçen ürünün yapışkan özellikte olduğu görülmektedir. Yumuşak segmentin molce daha düşük (sırasıyla molce $\% 20, \% 12,5$ ve $\% 8,3$ ) tutulduğu reçetelerin kullanımı ile elde edilen örneklerin ise bir kaplamadan beklenileni sağlayacak film özelliklerini başarı ile yerine getirdiği görülmektedir.

Poliol ve $\alpha, \omega$-hidroksi alkil telekelik PDMS oligomeri içeren kaplamalar ayrı ayrı değerlendirildiğinde poliol yerine aynı mol oranlarında $\alpha, \omega$-hidroksi alkil telekelik PDMS oligomeri kullanmanın yukarıda bahsedilen eğilimi değiştirmediği böylelikle $\alpha, \omega$-hidroksi alkil telekelik PDMS oligomerinin poliüretan kaplamaların hazırlanmasında çalışmamızda belirlenen oranlar dahilinde olmak şartıyla (sırasıly molce \%20, \%12,5 ve $\% 8,3$ ) başarıyla kullanılabileceği ortaya konmuştur.

Kullanılan farklı izosiyanat monomerleri açısından bir değerlendirme yapmak gerekirse, MDI monomerinin kullanımının, IPDI monomerinin kullanımına kıyasla renklenmeye (açık sarı renk) neden olduğu söylenebilir. Aromatik yapılardaki monomerlerin yapılarındaki delokalize elektronlar sebebiyle renklenmeye sebep olduğu bilinen bir gerçektir, çalışmamızda da aromatik yapıdaki MDI monomerinin kullanımı ile elde edilen kaplamaların açık sarı bir renk taşıdığı buna karşılık IPDI monomerinden elde edilen kaplamaların ise şeffaf olduğu görülmektedir. $\mathrm{Bu}$ renklenmenin dezavantaj oluşturabileceği uygulamalar için hazırlanacak poliüretan esaslı 
kaplamalarda MDI monomeri yerine IPDI monomeri tercih edilebileceği veya uygun pigment boyar madde ilavesi ile ürün arzu edilen görselliğe ulaştırılabileceği değerlendirilmektedir.

MDI monomeri ve poliol (PPG 2000) kullanılarak sentezlenen farklı zincir uzatıcı oranlarına sahip MP1, MP3 ve
MP5 kodlu poliüretan kaplamaların ATR FT-IR spektroskopisi yöntemi ile elde edilen spektrumları Şekil 3.1 de verilmektedir spektruma bakıldığında;

MDI monomerinin sahip olduğu $2260 \mathrm{~cm}^{-1}$ de gözlenen karakteristik izosiyanat titreşim pikinin kaybolması,

Tablo 3.1 Poliüretan Esaslı Kaplamaların Özellikleri.

\begin{tabular}{l|c|c}
\hline \multirow{2}{*}{$\begin{array}{c}\text { Polimer } \\
\text { Kodu }\end{array}$} & \multicolumn{2}{|c}{ Özellik } \\
\cline { 2 - 3 } MP0 & Film Oluşturma & Genel Görünüm \\
\hline MP1 & + & Yapışkan, Açık Sarı Renkli \\
\hline MP3 & + & Şeffaf film, Açı Sarı Renkli \\
\hline MP5 & + & Şeffaf film, Açık Sarı Renkli \\
\hline MS0 & - & Şeffaf film, Açık Sarı Renkli \\
\hline MS1 & + & Yapışkan, Açık Sarı Renkli \\
\hline MS3 & + & Şeffaf film, Açı Sarı Renkli \\
\hline MS5 & + & Şeffaf film, Açı Sarı Renkli \\
\hline IP0 & - & Şeffaf film, Açı Sarı Renkli \\
\hline IP1 & + & Yapışkan, Renksiz \\
\hline IP3 & + & Şeffaf film, Renksiz \\
\hline IP5 & + & Şeffaf film, Renksiz \\
\hline IS0 & - & Şeffaf film, Renksiz \\
\hline IS1 & + & Yapışkan, Renksiz \\
\hline IS3 & + & Şeffaf film, Renksiz \\
\hline IS5 & + & Şeffaf film, Renksiz \\
\hline
\end{tabular}

-CO-NH- bağına ait deformasyon titreşim pikinin $1532 \mathrm{~cm}^{-1} \mathrm{de}$ gözlenmesi ve PPG 2000'e ve MPG ye ait -CH gruplarına ait $2900-3000 \mathrm{~cm}^{-1}$ aralığındaki gözlenen pikler,

MDI ve PPG 2000 esaslı poliüretan kaplamaların başarı ile sentezlendiği ortaya koymaktadır.

MDI monomeri ve $\alpha, \omega$-hidroksi alkil telekelik PDMS oligomeri kullanılarak sentezlenen farklı zincir uzatıcı oranlarına sahip MS1, MS3 ve MS5 kodlu poliüretan kaplamaların ATR FT-IR spektroskopisi yöntemi ile elde edilen spektrumlar Şekil 3.2 de verilmektedir.

Şekil 3.2 de verilen spektruma bakıldığında;
MDI monomerinin sahip olduğu $2260 \mathrm{~cm}^{-1}$ de gözlenen karakteristik izosiyanat titreşim pikinin kaybolması,

-CO-NH- bağına ait deformasyon titreşim pikinin $1532 \mathrm{~cm}^{-1} \mathrm{de}$ gözlenmesi,

MPG ye ait $-\mathrm{CH}$ gruplarına ait 2900-3000 $\mathrm{cm}^{-1}$ aralığındaki gözlenen pikler ve

$\alpha, \omega$-hidroksi alkil telekelik PDMS oligomerinin yapısında bulunan Si-O-Si ve Si-CH3 gruplarına ait sirasıyla $1063 \mathrm{~cm}^{-1}$ ve $822 \mathrm{~cm}^{-1}$ de gözlenen pikler, MDI ve $\alpha, \omega$-hidroksi alkil telekelik PDMS oligomeri esaslı poliüretan kaplamaların başarı ile sentezlendiği ortaya koymaktadır.

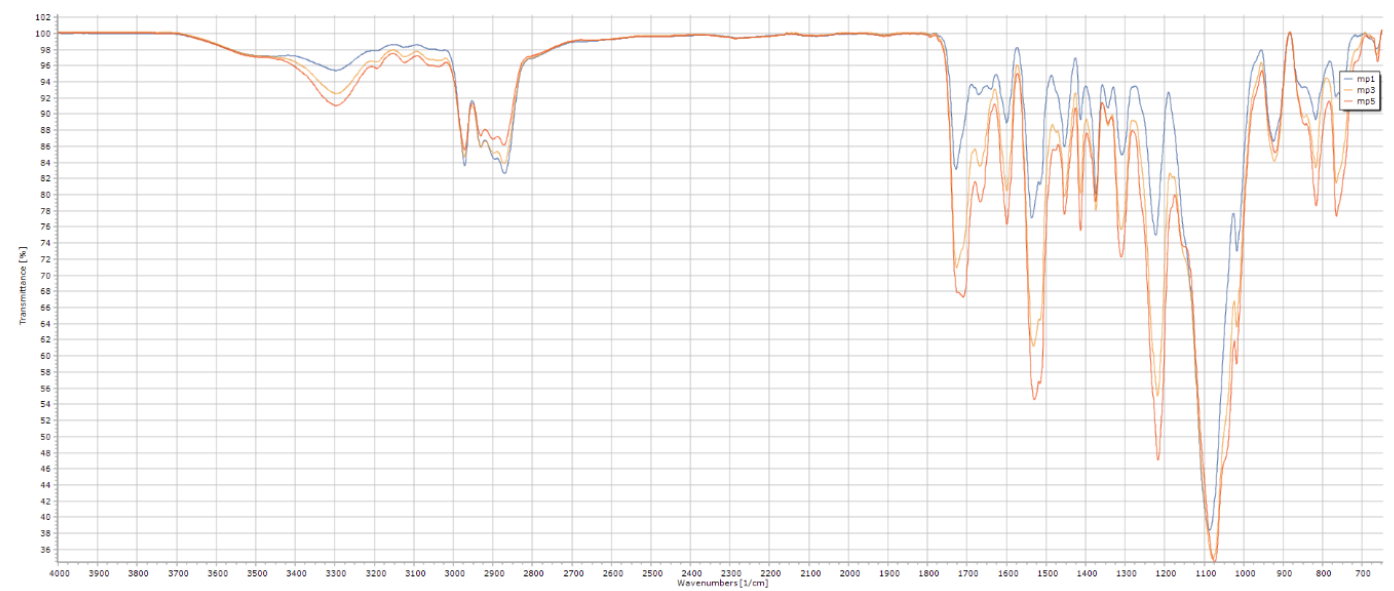

Şekil 3.1 MP1, MP3 ve MP5 Kodlu Poliüretan Kaplamaların ATR FT-IR Spektroskopisi Yöntemi İle Elde Edilen Spektrumlarl. 


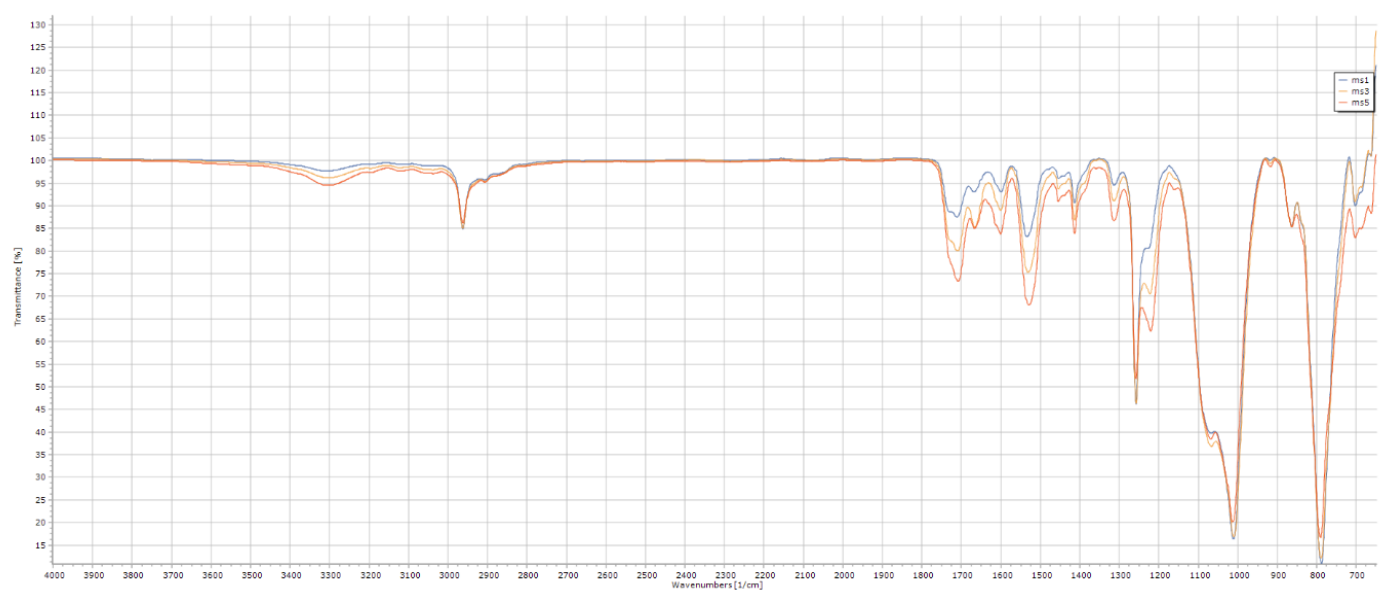

Şekil 3.2 MS1, MS3 ve MS5 Kodlu Poliüretan Kaplamaların ATR FT-IR Spektroskopisi Yöntemi Ile Elde Edilen Spektrumları.

.IPDI monomeri ve poliol (PPG 2000) kullanılarak sentezlenen farklı zincir uzatıcı oranlarına sahip IP1, IP3 ve IP5 kodlu poliüretan kaplamaların ATR FT-IR spektroskopisi yöntemi ile elde edilen spektrumlar Şekil 3.3 de verilmektedir. Şekil 3.3 de verilen spektruma bakıldığında;

IPDI monomerinin sahip olduğu $2260 \mathrm{~cm}^{-1}$ de gözlenen karakteristik izosiyanat titreşim pikinin kaybolması,

-CO-NH- bağına ait deformasyon titreşim pikinin $1532 \mathrm{~cm}^{-1}$ de gözlenmesi,

PPG 2000 ve MPG ye ait -CH gruplarına ait $2900-3000 \mathrm{~cm}^{-1}$ aralığındaki gözlenen pikler ve

IPDI ve PPG 2000 esaslı poliüretan kaplamaların başarı ile sentezlendiği ortaya koymaktadır.

IPDI monomeri ve $\alpha, \omega$-hidroksi alkil telekelik PDMS oligomeri kullanılarak sentezlenen farklı zincir uzatıcı oranlarına sahip IS1, IS3 ve IS5 kodlu poliüretan kaplamaların ATR FT-IR spektroskopisi yöntemi ile elde edilen spektrumlar Şekil 3.4 de verilmektedir.

Şekil 3.4 de verilen spektruma bakıldığında;

MDI monomerinin sahip olduğu $2260 \mathrm{~cm}^{-1}$ de gözlenen karakteristik izosiyanat titreşim pikinin kaybolması,

-CO-NH- bağına ait deformasyon titreşim pikinin $1532 \mathrm{~cm}^{-1}$ de gözlenmesi,

MPG ye ait -CH gruplarına ait $2900-3000 \mathrm{~cm}^{-1}$ aralı̆̆ındaki gözlenen pikler ve

$\alpha, \omega$-hidroksi alkil telekelik PDMS oligomerinin yapısında bulunan Si-O-Si ve Si-CH3 gruplarına ait sirasiyla $1063 \mathrm{~cm}^{-1}$ ve $822 \mathrm{~cm}-1$ de gözlenen pikler,

IPDI ve $\alpha, \omega$-hidroksi alkil telekelik PDMS oligomeri esaslı poliüretan kaplamaların başarı ile sentezlendiği ortaya koymaktadır.

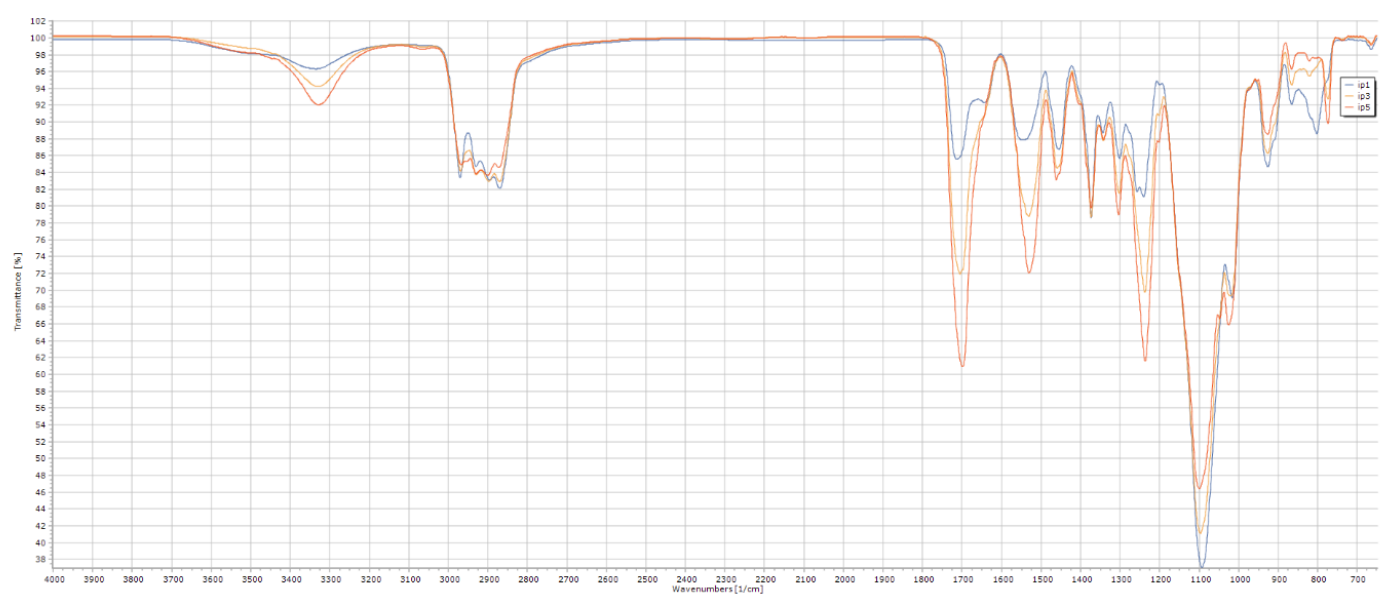

Şekil 3.3 IP1, IP3 ve IP5 Kodlu Poliüretan Kaplamaların ATR FT-IR Spektroskopisi Yöntemi Ile Elde Edilen Spektrumlarl. 


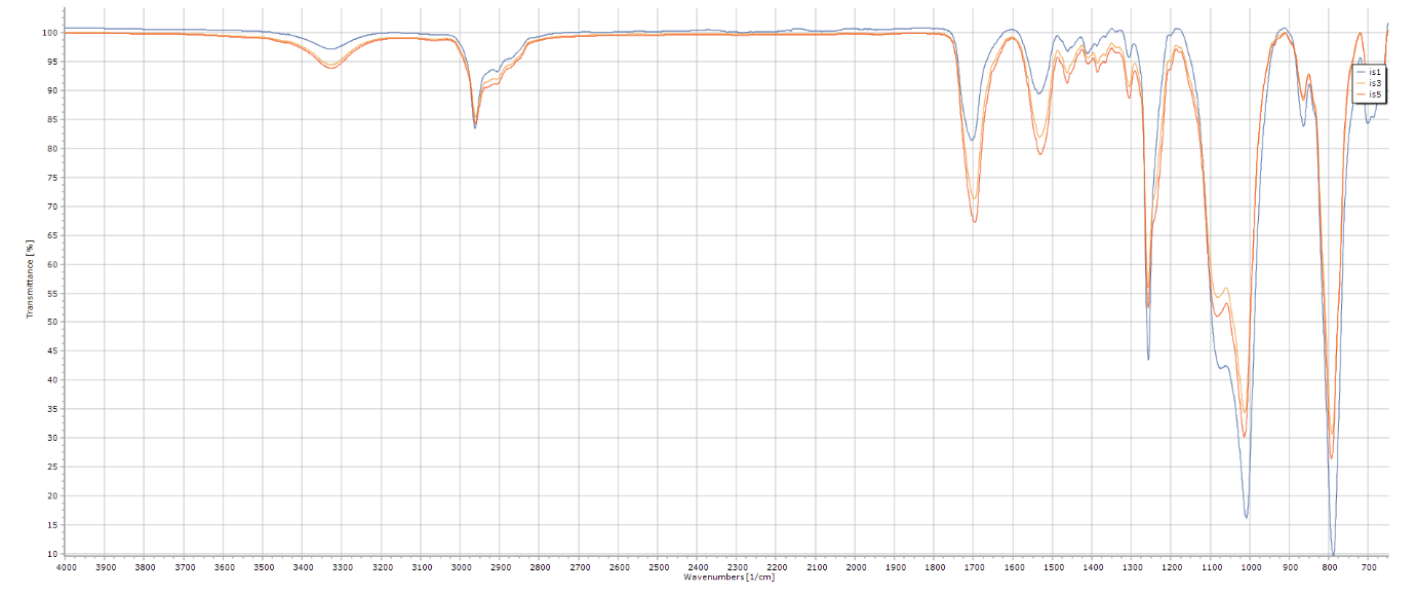

Şekil 3.4 IS1, IS3 ve IS5 Kodlu Poliüretan Kaplamaların ATR FT-IR Spektroskopisi Yöntemi İle Elde Edilen Spektrumları.

\subsection{Kaplamaların Mekanik Özellikleri}

Poliüretan esaslı kaplamaların ASTM D 638 standardına göre tespit edilen mekanik özellikleri aşağıda Tablo 3.2 de verilmektedir.

MP0, MS0, IP0 ve IS0 kodlu numuneler uygun nitelikte film oluşturamadıklarından bu örneklerin mekanik özellikleri tespit edilememiştir.

Elde edilen sonuçlara bakıldığında poliol (PPG 2000) kullanılarak hazırlanan örneklerin $\alpha, \omega$-hidroksi alkil telekelik PDMS oligomeri (Tegomer ${ }^{\circledR}$ H-Si 2315) kullanılarak hazırlanan aynı bileşimdeki örneklere kıyasla daha yüksek bir kopma mukavemeti sergiledikleri bunun yanında kopma uzaması değerlerinde ise düşüş eğilimi gösterdikleri ilk gözlenen olgu olarak not edilebilir. $\alpha, \omega$-hidroksi alkil telekelik PDMS oligomerinin (Tegomer ${ }^{\circledR}$ H-Si 2315) kullanılan poliole (PPG 2000) kıyasla daha elastik ve daha düşük mukavemet karakteristiğinde olması nedeniyle bu özellikleri poliüretan yapılarına aktarması elde edilen sonuçlarla da desteklendiği üzere beklenen bir durumdur denilebilir. Ayrıca poliüretan zincirlerinde artan yumuşak segment miktarının kopma mukavemetinde azalmaya ve kopma uzaması değerlerinde artışa sebep olduğu görülmektedir. Bir polimerde ve özelde de poliüretan örneğinde malzemeye uygulanan yükü ilk elden üstelenen, gerilime karş1 direnç gösteren yapıların kristalin formda olan sert segmentler olduğu bilinen bir gerçektir. Zincir yapısındaki yumuşak segmentler ise mekanik özellikler açısından darbe dayanım ve uzama özelliklerinin belirginleşmesinde önemli rol oynarlar.

Farklı yumuşak:sert segmentlere sahip olacak şekilde tasarlanarak sentezlenen poliüretan kaplama örneklerinin mekanik olarak incelenmesinden elde edilen sonuçlar bu genel çerçeve ile uyum içindedir. Yüksek oranlarda sert segment içeren örnekler daha yüksek kopma mukavemetlerine sahip iken uzama değerlerinde düşüş gözlenmektedir. Yüksek oranlarda yumuşak segmentlere sahip örneklerde ise gözlenen durum bunun tam tersi şekilde kendinin ortaya koymaktadır. Özetle hazırlanacak kaplamaların uygulama gereksinimleri neyi gerektiriyorsa, bu performansı sağlayacak nitelikte mekanik özelliklere sahip kaplamalar yumuşak:sert segmentlerin oranlarındaki değişikliklerle hazırlanabilir. $\mathrm{Bu}$ konfigürasyonlara ulaşmak için ise sentezlenecek poliüretanın bileşiminde yer alan poliol veya
PDMS ile zincir uzatıcının başlangıç miktarları belirlenmesi ve çalışmamızda ortaya koyduğumuz yöntemle sentezlenmesi yeterli olacaktır.

Formülasyonlarda kullanılan izosiyanat monomerinin farklılandırılması ile hazırlanan örneklerden elde edilen sonuçlara bakıldığında; MDI monomeri kullanılarak hazırlanan poliüretan örneklerinin IPDI monomeri kullanılarak hazırlanan poliüretan örneklerinin aynı bileşimdekilerine kıyasla daha yüksek bir kopma mukavemeti ve daha düşük kopma uzaması değerlerine sahip olduğu tespit edildi. MDI monomerinden hazırlanan örneklerin sergilediği bu davranış MDI monomerinin aromatik yapıya sahip olması ile açıklanabilir, yüksek performanslı polimerlerin genellikle aromatik yapıdaki monomerleri yapısında bulundurduğu, alifatik monomerleri içeren polimerlerin ise daha düşük mekanik özellikler sergileyen yaygın (commodity) polimer ailesine dahil oldukları bilinen bir gerçektir. Bu gerçek çalışmamızda hazırlanan poliüretan örneklerinde de aynı eğilimi sergiler şekilde karşımıza çıkmaktadır.

\subsection{Kaplamaların Sertlik Özellikleri}

Poliüretan esaslı kaplamaların ASTM D 2240 standardına göre tespit edilen sertlik değerleri aşağıda Tablo 3.3 de verilmektedir.

MP0, MS0, IP0 ve IS0 kodlu numuneler uygun nitelikte film oluşturamadıklarından bu örneklerin sertlik özellikleri tespit edilememiştir.

Sonuçlara bakıldığında tüm poliüretan kaplama örneklerinde artan zincir uzatıcı oranına bağlı olarak sertlik değerlerinde artış olduğu görülmektedir. Zincir uzatıcı bileşik (MPG) kısa zincir yapısıyla polimer zincirlerindeki sert segmentlerin miktarını arttırması ortaya çıkan bu eğilimi anlaşılır kılmaktadır.

Poliüretan kaplamaların sertlik değerlerine karşılaştırılmalı bakıldığında $\alpha, \omega$-hidroksi alkil telekelik PDMS oligomeri (Tegomer ${ }^{\circledR}$ H-Si 2315) kullanılarak hazırlanan aynı bileşimdeki örneklerin Poliol (PPG 2000) kullanılarak hazırlanan aynı bileşimdeki örneklere kıyasla daha düşük sertlik değerlerine sahip olduğu görülmektedir. PDMS zincirlerinin sahip olduğu poliollere kıyasla daha yüksek elastisite karakteristiği kaplamaların sertlik değerlerinde de baskın bir rol oynayarak aynı sıcaklık değerlerinde daha elastomerik ve yumuşak yapıda ürünler ortaya çıkmasına imkân verdiği değerlendirilebilir. 
Tablo 3.2 Poliüretan Esaslı Kaplamaların ASTM D 638 Standardına Göre Belirlenen Mekanik Özellikleri.

\begin{tabular}{l|c|c}
\hline $\begin{array}{c}\text { Polime } \\
\mathbf{r} \\
\text { Kodu }\end{array}$ & \multicolumn{2}{|c}{ Özellik } \\
\cline { 2 - 3 } & $\begin{array}{c}\text { Kopma } \\
\text { Mukavemeti } \\
\text { (MPa) }\end{array}$ & $\begin{array}{c}\text { Kopma Uzamasi } \\
\text { (\%) }\end{array}$ \\
\hline MP0 & Belirlenemedi & Belirlenemedi \\
\hline MP1 & 1,13 & 230 \\
\hline MP3 & 2,34 & 175 \\
\hline MP5 & 5,15 & 80 \\
\hline MS0 & Belirlenemedi & Belirlenemedi \\
\hline MS1 & 0,84 & 585 \\
\hline MS3 & 1,45 & 350 \\
\hline MS5 & 4,24 & 280 \\
\hline IP0 & Belirlenemedi & Belirlenemedi \\
\hline IP1 & 0,94 & 760 \\
\hline IP3 & 1,66 & 640 \\
\hline IP5 & 2,64 & 435 \\
\hline IS0 & Belirlenemedi & Belirlenemedi \\
\hline IS1 & 0,56 & $>900$ \\
\hline IS3 & 1,17 & 780 \\
\hline IS5 & 2,35 & 540 \\
\hline
\end{tabular}

Tablo 3.3 Poliüretan Esaslı Kaplamaların ASTM D 2240 Standardına Göre Tespit Edilen Sertlik Değerleri.

\begin{tabular}{l|c}
\hline \multicolumn{1}{c|}{ Polimer } & $\begin{array}{c}\text { Sertlik Değeri } \\
\text { (Shore A) }\end{array}$ \\
\hline MP0 & Belirlenemedi \\
\hline MP1 & 50 \\
\hline MP3 & 65 \\
\hline MP5 & 75 \\
\hline MS0 & Belirlenemedi \\
\hline MS1 & 32 \\
\hline MS3 & 45 \\
\hline MS5 & 85 \\
\hline IP0 & Belirlenemedi \\
\hline IP1 & 60 \\
\hline IP3 & 75 \\
\hline IP5 & 90 \\
\hline IS0 & Belirlenemedi \\
\hline IS1 & 40 \\
\hline IS3 & 55 \\
\hline IS5 & 80 \\
\hline
\end{tabular}

Formülasyonlarda izosiyanat tipinin değiştirilmesi hazırlanan farklı poliüretanların sertlik değerleri değişen izosiyanat tipine göre incelendiğinde aynı bileşimde olmak şartıyla IPDI ile hazırlanan örneklerin sertlik değerlerinin MDI ile hazırlanan örneklerin sertlik değerlerinden daha yüksek olduğu görülmektedir. Alifatik yapıdaki IPDI monomerine kıyasla aromatik yapıdaki MDI monomerinin moleküler açıdan daha yüksek rijitlik sergilemesi, yüksek kristaliniteye imkân sağlaması ve dolayısıyla daha sert filmler oluşturması beklenirken tespit edilen sonuçlar farklı bir eğilim ortaya koymaktadır. Bu durum IPDI monomerinin ve MDI monomerinin kimyasal yapisina bakıldığında görülebilecek izosiyanat gruplarının konum ve aralarındaki var olan diğer gruplar ve birbirlerine olan mesafeleri açısından değerlendirildiğinde açıklanabilir olmaktadır. IPDI monomeri aynı siklik halka üzerinde ve birbirlerine oldukça yakın konumda -NCO grupları içerirken, MDI monomerindeki -NCO gruplarının iki ayrı aromatik halka üzerinde bulunduğu ve bu halkaları birbirlerine bağlayan bir alifatik yapıya sahip olduğu görülmektedir. Bu bilgiler ışığında IPDI monomerinin poliüretan zincirlerinde MDI monomerine kıyasla daha yakın üretan bağlarının oluşmalarını sağladıkları söylenebilir. Bilindiği gibi üretan bağları poliüretan zincirlerinde sert segmentlerin oluşmasının asli unsurlarından biridir. Sonuç olarak kullanılan izosiyanatın tipinin aromatik veya alifatik olmasının yanında molekül üzerindeki serbest harekete imkân verecek üretan bağlarını oluşturacak -NCO gruplarının birbirlerine uzaklığı ve - 
NCO grupları arasındaki diğer fonksiyonel grupların da sertlik değerleri üzerinde etkin rol oynadıkları söylenebilir.

\subsection{Kaplamaların Termal Dayanım Özellikleri}

Poliüretan esaslı kaplamaların TGA yöntemi ile belirlenen termal dayanım özellikleri, artan sıcaklığa bağlı olarak örneklerin bozunma karakteristiğini ortaya koyacak şekilde örneklerin başlangıç miktarlarından kalan yüzdelik kütle miktarı ve buna karşılık gelen sıcaklık değerleri ve maksimum DTG değerleri olarak Tablo 3.4 de verilmektedir.

MP0, MS0, IP0 ve IS0 kodlu numuneler uygun nitelikte film oluşturamadıklarından bu örneklerin termal özellikleri incelenmedi.

Sonuçlara bakıldığında MDI ve IPDI esaslı ve poliol içeren iki tip poliüretan kaplama serisinin de iki aşamalı bir bozunma gösterdikleri elde edilen maksimum DTG piklerinden görülmektedir. MDI (MP1, MP3 ve MP5 kodlu) serisi ve IPDI (IP1, IP3 ve IP5 kodlu) serisinden ele geçen sirasıyla $\% 5$, \%10, $\% 50$ ve $\% 90$ oranındaki kütle azalma miktarı sıcaklıklarının birbirlerine yakın değerlere sahip olduğu tespit edildi. Maksimum DTG ve $\% 5, \% 10, \% 50$ ve $\% 90$ oranındaki kütle kalıntılarının kaldığı sıcaklık değerleri topluca incelendiğinde poliol içeren MDI esaslı poliüretan kaplamalar ile IPDI esaslı poliüretan kaplamaların benzer termal bozunma karakteristiği sergiledikleri kolaylıkla söylenebilir.

MS1, MS3 ve MS5 kodlu MDI esaslı ve IS1, IS3 ve IS5 kodlu IPDI esaslı $\alpha, \omega$-hidroksi alkil telekelik PDMS oligomeri içeren kaplamaların ilgili değerlerine bakıldığında ise ilk göze çarpan hususun elde edilen maksimum DTG piklerinden görülebileceği gibi MDI ve IPDI esaslı poliol içeren örneklerin aksine termal bozunmanın iki değil üç aşamalı şekilde gerçekleştiğinin tespiti olduğu söylenebilir. Bahsi geçen üçüncü aşamanın daha yüksek sıcaklık değerlerinde ve ayrı bir maksimum DTG piki şeklinde ortaya çıkması yapıya giren $\alpha, \omega$-hidroksi alkil telekelik PDMS oligomerinin poliüretan kaplamanın termal dayanımına önemli bir katkısı olarak değerlendirilmelidir.

Ayrıca $\% 5, \% 10, \% 50$ ve $\% 90$ oranındaki kütle azalma miktarı sıcaklıkları açısından MS1, MS3 ve MS5 kodlu MDI esaslı ve IS1, IS3 ve IS5 kodlu IPDI esaslı $\alpha, \omega$-hidroksi alkil telekelik PDMS oligomeri içeren kaplamaların ilgili değerlerine bakıldığında termal bozunma işleminin başlangıcında ( $\% 5, \% 10)$ görece daha düşük sıcaklık değerleri görülürken işlemin ilerleyen aşamalarında (\%50 ve üstü oranlarda) poliol içeren örneklere kıyasla daha yüksek sıcaklık değerlerine ulaştığı görülmektedir. $\mathrm{Bu}$ durum yapıdaki $\alpha, \omega$-hidroksi alkil telekelik PDMS oligomerinin kaplamalarda ilk olarak bozunan uçucu bileşenleri koruyamadığı \%5, \%10 oranındaki kütle azalmasının düşük sıcaklıklarda görece daha kolay gerçekleştiği ancak poliüretan yapının ana zincirindeki temel bileşenleri ise çok daha başarılı bir şekilde koruduğu sonucuna bizi ulaştırmaktadır.

Tüm bu değerlendirmeler ışığında poliüretan kaplama yapısına $\alpha, \omega$-hidroksi alkil telekelik PDMS oligomerinin dahil edilmesinin kaplamaların termal bozunma dayanımlarını iyileştirdiği değerlendirilmektedir.

Tablo 3.4 Poliüretan Esaslı Kaplamaların TGA Sonuçları.

\begin{tabular}{l|c|c|c|c|c|c}
\hline $\begin{array}{c}\text { Polime } \\
\mathbf{r} \\
\text { Kodu }\end{array}$ & $\begin{array}{c}\mathbf{T} \% \mathbf{5} \\
{ }^{\circ} \mathbf{C}\end{array}$ & $\begin{array}{c}\mathbf{T} \% \mathbf{1 0} \\
{ }^{\circ} \mathbf{C}\end{array}$ & $\begin{array}{c}\mathbf{T} \% \mathbf{5 0} \\
{ }^{\circ} \mathbf{C}\end{array}$ & $\begin{array}{c}\mathbf{T} \% \mathbf{9 0} \\
{ }^{\circ} \mathbf{C}\end{array}$ & $\begin{array}{c}\mathbf{D T G} \text { max } \\
{ }^{\circ} \mathbf{C}\end{array}$ & $\begin{array}{c}\text { \% KalıntI @ } \\
\mathbf{7 0 0}{ }^{\circ} \mathbf{C}\end{array}$ \\
\hline MP0 & - & - & - & - & - & - \\
\hline MP1 & 264 & 309 & 383 & 415 & $258 / 392$ & 4,27 \\
\hline MP3 & 247 & 274 & 382 & 463 & $260 / 395$ & 6,80 \\
\hline MP5 & 239 & 263 & 375 & 473 & $264 / 393$ & 6,65 \\
\hline MS0 & - & - & - & - & - & - \\
\hline MS1 & 232 & 275 & 447 & 545 & $233 / 306 / 470$ & 3,41 \\
\hline MS3 & 231 & 247 & 436 & 552 & $244 / 315 / 475$ & 3,99 \\
\hline MS5 & 216 & 239 & 369 & 534 & $256 / 324 / 474$ & 5,91 \\
\hline IP0 & - & - & - & - & - & - \\
\hline IP1 & 269 & 303 & 357 & 400 & $269 / 386$ & 0,40 \\
\hline IP3 & 255 & 273 & 321 & 385 & $276 / 376$ & 1,32 \\
\hline IP5 & 248 & 268 & 315 & 386 & $283 / 375$ & 1,77 \\
\hline IS0 & - & - & - & - & - & - \\
\hline IS1 & 226 & 263 & 386 & 443 & $231 / 342 / 379$ & 1,21 \\
\hline IS3 & 220 & 241 & 365 & 472 & $253 / 342 / 403$ & 0,75 \\
\hline IS5 & 216 & 239 & 348 & 469 & $257 / 342 / 427$ & 0,39 \\
\hline
\end{tabular}

\subsection{Kaplamaların Yapışma Kuvvetinin Belirlenmesi}

Poliüretan esaslı kaplamaların ASTM D 3359 standardına göre Çapraz Kesim (Cross Cut) Adhezyon testi ile tespit edilen yapışma özellikleri aşağıda Tablo 3.5 de verilmektedir.

Bir kaplamanın uygulanan yüzeye iyi şekilde yapışması koruma ve yalıtım açısından performans gösterebilmesi adına beklenen en önemli özelliklerden biridir. Yetersiz etkileşim düşük adhezyon karakteristiği kaplamanın yüzeyden ayrılmasına yol açacağından, yüzeyin korumasız kalmaması adına bu özelliğin ortaya konması önem arz etmektedir.

Tablo 3.5 deki verilere bakıldığında en yüksek yumuşak segment (molce \%50) oranına sahip MP0, MS0, IP0 ve IS0 kodlu örneklerin uygun nitelikte film oluşturmamaları sebebiyle 
değerlendirilememeleri haricindeki tüm örneklerin ilgili standarda göre en yüksek yapışma derecesi sınıfına ait 5B sınıfına girdiği görülmektedir.
En yüksek yapışma derecesine sahip olan örneklerin bu sonuçlar ışı̆̆ında kaplama uygulamaları için yüksek performans ortaya koyacak nitelikte olduğu rahatlıkla söylenebilir.

Tablo 3.5 Poliüretan Esaslı Kaplamaların ASTM D 3359 Standardına Göre Belirlenen Yapışma Dereceleri.

\begin{tabular}{|c|c|c|}
\hline \multirow{2}{*}{$\begin{array}{c}\text { Polimer } \\
\text { Kodu }\end{array}$} & \multicolumn{2}{|c|}{ Yapıșma Derecesi* } \\
\hline & Beton Yüzey & Metal Yüzey \\
\hline MP0 & Belirlenemedi & Belirlenemedi \\
\hline MP1 & $5 \mathrm{~B}$ & $5 \mathrm{~B}$ \\
\hline MP3 & $5 B$ & $5 B$ \\
\hline MP5 & $5 B$ & $5 B$ \\
\hline MS0 & Belirlenemedi & Belirlenemedi \\
\hline MS1 & $5 \mathrm{~B}$ & $5 \mathrm{~B}$ \\
\hline MS3 & $5 B$ & $5 B$ \\
\hline MS5 & $5 \mathrm{~B}$ & $5 \mathrm{~B}$ \\
\hline IP0 & Belirlenemedi & Belirlenemedi \\
\hline IP1 & $5 \mathrm{~B}$ & $5 \mathrm{~B}$ \\
\hline IP3 & $5 B$ & $5 B$ \\
\hline IP5 & $5 \mathrm{~B}$ & $5 \mathrm{~B}$ \\
\hline IS0 & Belirlenemedi & Belirlenemedi \\
\hline IS1 & $5 \mathrm{~B}$ & $5 \mathrm{~B}$ \\
\hline IS3 & $5 B$ & $5 B$ \\
\hline IS5 & $5 B$ & $5 B$ \\
\hline
\end{tabular}

*ASTM D 3359 Standardına göre yapışma dereceleri:

5B = En iyi derecelendirme: Kesimlerin kenarları tamamen pürüzsüzdür; düzlem karelerinin hiçbiri ayrılmamıştır.

4B = 5B den daha kötü: Kaplamanın kesim birleşimlerinde alanın \%5'inden az oranda ayrılma gözlenir.

3B = 4B den daha kötü: Kaplamanın kesim birleşimleri ve kenarlarında alanın \%5- 15 oranında ayrılma gözlenir.

2B = 3B den daha kötü: Kaplamanın kenarlarında ve karelerde alanın \%15- 35 oranında ayrılma gözlenir.

1B = 2B den daha kötü: Kaplamanın kenarlarında ve yüzeyde şerit şeklinde alanın \%35- 65 oranında ayrılma gözlenir.

$0 \mathrm{~B}=$ En kötü derecelendirme: Pul şeklinde kalkma ve tüm yüzeyden ayrılma

\subsection{Kaplamaların Su Yalıtım Özelliğinin Belirlenmesi}

Poliüretan esaslı kaplamaların BS EN 1928 standardı Metot A'ya göre tespit edilen su yalıtım özellikleri aşağıda Tablo 3.6 de verilmektedir.MP0, MS0, IP0 ve IS0 kodlu numuneler uygun nitelikte film oluşturamadıklarından bu örneklerin su yalıtım özellikleri tespit edilememiştir.

Su sızdırmazlık tekstil ürünlerinden kaplamalara, boyalardan sızdırmazlık elemanlarına kadar pek çok sektörde dikkat edilen önemli bir parametredir. Bilindiği gibi suyun bir fazdan geçişi uyguladığı veya uygulanan basınca sıkı sıkıya bağlıdır. Örneğin bir conta normal şebeke basıncında başarı ile çalışabilirken yüksek basınçlı bir ortamda bu özelliğini koruyamayabilir. Bu ilişki nedeniyle su sızdırmazlık (watertightness/waterproofing) performansının belirlenmesinde örnekler belli basınçlardaki suya maruz bırakılarak suyu geçirip geçirmedikleri tespit edilir.

Hazırlanan poliüretan örneklerinden film oluşturma özelliğine sahip olan örneklerin bu test ile incelenmesinde Tablo 3.6 de özetlenen sonuçlara ulaşıldı.

$\mathrm{Bu}$ sonuçlara göre örneklerin $500 \mathrm{~mm}$ ve $750 \mathrm{~mm}$ su sütun yüksekliklerindeki basınç değerlerinde 24 saat süre ile tutulduklarında örnek üstüne yerleştirilen filtre kağıdında renklenme gözlenmediği görüldü.

Böylece örneklerin su sızdırmadığ (watertight/waterproof) sınıfinda olduğu belirlendi.

\subsection{Kaplamaların Yanma Davranışının Belirlenmesi}

Poliüretan esaslı kaplamaların UL 94 standardına göre tespit edilen yanma davranışları aşağıda Tablo 3.7 de verilmektedir.

MP0, MS0, IP0 ve IS0 kodlu numuneler uygun nitelikte film oluşturamadıklarından bu örneklerin yanma davranış özellikleri tespit edilememiştir.

UL 94 standardına göre sinıflandırılmalar yapılırken en kötü sınıfa örnek olarak gösterilen poliüretanların yanma davranışlarının iyileştirilmesi çalışmamızın odağında bulunduğu bilgisi ile Tablo 3.7 deki sonuçlara bakıldığında yanma özellikleri açısından en problemli polimer tipi olan poliüretanların genel karakteristiği ile karşılaşılmaktadır.

Poliol (PPG 2000) kullanılarak hazırlanan tüm poliüretan kaplama örneklerinin ilgili teste tabi tutulduğunda yanmaya devam ettikleri, kendilerini söndüremedikleri bu nedenle de UL 94 standardının belirlediği sınıflandırmalara giremeyerek en kötü sonuçlara sahip oldukları tespit edildi.

Bununla beraber $\alpha, \omega$-hidroksi alkil telekelik PDMS oligomeri (Tegomer® H-Si 2315) kullanılarak hazırlanan örnekler teste tabi tutulduğunda alevin çekilmesini takiben hemen alevin söndüğü ancak alevli olmayan damlama yaptığı görüldü. 
Kimyasal yapısı nedeniyle son derece yanıcı özellik sergileyen hidrokarbon yapılı poliollerin aksine, poliüretan yapıya farklı oranlarda dahil olan $\alpha, \omega$-hidroksi alkil telekelik PDMS oligomerinin (Tegomer® H-Si 2315) sahip olduğu yanmazlık özelliğini başarı ile poliüretan kaplamanın yanma davranışı özelliklerine aktardığg görülmektedir.

Tablo 3.6 Poliüretan Esaslı Kaplamaların BS EN 1928 Standardı Metot A'ya Göre Belirlenen Su Yalıtım Özellikleri.

\begin{tabular}{|c|c|c|}
\hline \multirow{2}{*}{$\begin{array}{c}\text { Polimer } \\
\text { Kodu }\end{array}$} & \multicolumn{2}{|c|}{ Basınç (Su Sütun Yüksekliği) } \\
\hline & $500 \mathrm{~mm}$ & $750 \mathrm{~mm}$ \\
\hline MP0 & Belirlenemedi & Belirlenemedi \\
\hline MP1 & Sizdırma Yok & Sizdırma Yok \\
\hline MP3 & Sizdırma Yok & Sizdırma Yok \\
\hline MP5 & Sizdırma Yok & Sizdırma Yok \\
\hline MS0 & Belirlenemedi & Belirlenemedi \\
\hline MS1 & Sizdirma Yok & Sizdırma Yok \\
\hline MS3 & Sizdırma Yok & Sizdırma Yok \\
\hline MS5 & Sizdırma Yok & Sizdırma Yok \\
\hline IP0 & Belirlenemedi & Belirlenemedi \\
\hline IP1 & Sizdırma Yok & Sizdırma Yok \\
\hline IP3 & Sizdırma Yok & Sizdırma Yok \\
\hline IP5 & Sizdırma Yok & Sizdırma Yok \\
\hline IS0 & Belirlenemedi & Belirlenemedi \\
\hline IS1 & Sizdırma Yok & Sizdırma Yok \\
\hline IS3 & Sizdırma Yok & Sizdırma Yok \\
\hline IS5 & Sizdırma Yok & Sizdirma Yok \\
\hline
\end{tabular}

Poliüretan esaslı kaplamaların ASTM D 635 standardına göre tespit edilen yatay yanma hızları aşağıda Tablo 3.7 de verilmektedir.MP0, MS0, IP0 ve IS0 kodlu numuneler uygun nitelikte film oluşturamadıklarından bu örneklerin yatay yanma hızları tespit edilememiştir. Sonuçlara bakıldığında poliol (PPG 2000) esaslı poliüretan kaplamaların yüksek hızlarda yandığı (810 s) buna karşılık $\alpha, \omega$-hidroksi alkil telekelik PDMS oligomeri (Tegomer ${ }^{\circledR}$ H-Si 2315) esaslı poliüretan kaplamalarda alevin ilerlemediği tespit edildi. $\alpha, \omega$-hidroksi alkil telekelik PDMS oligomerinin (Tegomer ${ }^{\circledR} \mathrm{H}-\mathrm{Si}$ 2315) poliüretan yapısına katılması ile elde edilen UL 94 standardına göre sınıflandırmaya bile giremeyen örneklerin en iyi sınıf olan V0 sınıfı değerlerine ulaştırılabilmesi ve yatay yanma hızları açısından elde edilen sonuçlar, çalışmamızın odağında bulunan ve en öncelikli çabamız olan poliüretan kaplamaların yanma davranışlarının iyileştirilmesi amacına başarı ile ulaşıldığının önemli delilleri olarak değerlendirilebilir.

Tablo 3.7 Poliüretan Esaslı Kaplamaların UL 94 Standardına Göre Tespit Edilen Yanma Davranışı Özellikleri ve Yanma Hızları.

\begin{tabular}{l|c|c}
\hline \multicolumn{1}{c|}{ Polimer Kodu } & Yanma Davranışı* & Yanma Huzları (s)*** \\
\hline MP0 & Belirlenemedi & Belirlenemedi \\
\hline MP1 & Sinıflandırma D1ş1** & $\sim 10$ \\
\hline MP3 & Sinıflandırma D1ş1** & $\sim 10$ \\
\hline MP5 & Sinıflandırma D1ş1** & $\sim 10$ \\
\hline MS0 & Belirlenemedi & Belirlenemedi \\
\hline MS1 & V0 & Alev ilerlemedi \\
\hline MS3 & V0 & Alev ilerlemedi \\
\hline MS5 & V0 & Alev ilerlemedi \\
\hline IP0 & Belirlenemedi & Belirlenemedi \\
\hline IP1 & Sinıflandırma D1ş1** & $\sim 8$ \\
\hline IP3 & Sinıflandırma D1ş1** & $\sim 8$ \\
\hline IP5 & Sinıflandırma Diş1** & $\sim 8$ \\
\hline IS0 & Belirlenemedi & Belirlenemedi \\
\hline IS1 & V0 & Alev ilerlemedi \\
\hline IS3 & V0 & Alev ilerlemedi \\
\hline IS5 & V0 & Alev ilerlemedi \\
\hline
\end{tabular}

${ }^{*}$ UL 94 Standartına göre yanma sınıfları:

V0 = Örnekte alev çekildikten sonra 10 saniye içinde yanma durur; alevli damlama olmamalıdır.

$\mathrm{V} 1=$ Örnekte alev çekildikten sonra 30 saniye içinde yanma durur; alevli damlama olmamalıdır.

V2 = Örnekte alev çekildikten sonra 30 saniye içinde yanma durur; alevli damlama olabilir.

** Örnekler alev çekildikten sonra yanmaya devam ettiği, sönme gözlenmediğinden sınıflandırmaya girmedi.

*** ASTM D 635 standardına göre tespit edilen yatay yanma hizları. 


\section{Sonuçlar}

Farklı molekül ağırlığına sahip polioller, MPG zincir uzatıc1sı, MDI, IPDI monomerleri ve $\alpha, \omega$-hidroksi alkil telekelik PDMS oligomeri kullanılarak çeşitli bileşimlerde poliüretan kaplamalar başarı ile sentezlendi.

Sentezlenen poliüretan kaplamaların yapısal karakterizasyonları ATR FT-IR spektroskopisi yöntemi ile doğrulandı. Film oluşturma, görünüm, mekanik özellikler, termal dayanım, kaplama performans parametreleri olan yapışma kuvveti, su yalıtım özellikleri ve projemizin en önemli aşaması olan yanma dayanım özellikleri yönünden incelenen poliüretan kaplamaların bileşim performans özellikleri ortaya konuldu.

Elde edilen sonuçlar aşağıda özetlenmektedir:

Farklı molekül ağırlığına sahip çeşitli poliol türleri arasından film oluşturma özellikleri başta olmak üzere diğer özellikler açısından kullanıma en uygun poliolün $2000 \mathrm{~g} / \mathrm{mol}$ molekül ağırlığına sahip olan PPG 2000 olduğu tespit edildi.

$\alpha, \omega$-hidroksi alkil telekelik PDMS oligomeri içeren PU/PDMS blok kopolimerlerin hazırlanmasında kullanılabilecek alternatif çözücü veya çözücü karışımı için en uygun seçimin hacimce 3:1 oranında olacak şekilde THF:DMAc çözücü karışımı olduğu tespit edildi.

Poliüretan kaplamaların molce $\% 50$ oranında yüksek yumuşak segmente (molce yüksek oranda poliol veya $\alpha, \omega$ hidroksi alkil telekelik PDMS oligomeri içeren) sahip örneklerin film oluşturma özelliklerinin zayıf olduğu, ele geçen ürünün yapışkan özellikte olduğu, yumuşak segmentin molce daha düşük (sırasıyla molce $\% 20, \% 12,5$ ve $\% 8,3$ ) tutulduğu reçetelerin kullanımı ile elde edilen örneklerin ise bir kaplamadan beklenileni sağlayacak film özelliklerini başarı ile yerine getirdiği tespit edildi.

Mekanik özellikler penceresinden sentezlenen örnekler incelendiğinde poliol (PPG 2000) kullanılarak hazırlanan örneklerin $\alpha, \omega$-hidroksi alkil telekelik PDMS oligomeri (Tegomer ${ }^{\circledR}$ H-Si 2315) kullanılarak hazırlanan aynı bileşimdeki örneklere kıyasla daha yüksek bir kopma mukavemeti sergiledikleri bunun yanında kopma uzaması değerlerinde ise düşüş eğilimi gösterdikleri tespit edildi. Yüksek oranlarda sert segment içeren tüm örneklerin daha yüksek kopma mukavemetlerine sahip iken uzama değerlerinde düşüş gözlenmektedir. Yüksek oranlarda yumuşak segmentlere sahip örneklerde ise gözlenen durum bunun tam tersi şekilde kendinin ortaya koymaktadır. Sentezlenen poliüretan kaplamalarda yumuşak segment olarak kullanılan poliol veya $\alpha, \omega$-hidroksi alkil telekelik PDMS oligomerinin yapıdaki molce oranı arttıkça beklenildiği gibi mukavemet değerlerinde azalma olduğu buna karşılık uzama ve elastiklik değerlerinde iyileşme olduğu tespit edildi.

Özetle hazırlanacak kaplamaların uygulama gereksinimleri neyi gerektiriyorsa, bu performansı sağlayacak nitelikte mekanik özelliklere sahip kaplamalar yumuşak:sert segmentlerin oranlarındaki değişikliklerle hazırlanabilecekleri, bu konfigürasyonlara ulaşmak için ise sentezlenecek poliüretanın bileşiminde yer alan poliol veya PDMS ile zincir uzatıcının başlangıç miktarları belirlenmesi ve çalışmamızda ortaya koyduğumuz yöntemle sentezlenmesi yeterli olacağ ulaşıldı.
Uygun nitelikte film oluşturabilen tüm poliüretan kaplamalarda artan zincir uzatıcı oranına bağlı olarak sertlik değerlerinde artış olduğu tespit edildi.

Poliüretan kaplama yapısına $\alpha, \omega$-hidroksi alkil telekelik PDMS oligomerinin dahil edilmesinin kaplamaların termal bozunma dayanımlarını iyileştirdiği tespit edildi.

Uygun nitelikte film oluşturabilen tüm poliüretan kaplamaların ilgili standarda göre en yüksek yapışma derecesi sınıfına ait 5B sınıfına girdiği tespit edildi.

Uygun nitelikte film oluşturabilen tüm poliüretan kaplamaların $500 \mathrm{~mm}$ ve $750 \mathrm{~mm}$ su sütun yüksekliklerindeki basınç değerlerinde 24 saat süre ile tutulduklarında örnek üstüne yerleştirilen filtre kağıdında renklenme gözlenmediği görüldü. Böylece örneklerin su sızdırmadığı, su geçirmez (watertight/waterproof) sınıfinda olduğu belirlendi.

Poliol (PPG 2000) kullanılarak hazırlanan tüm poliüretan kaplama örneklerinin ilgili teste tabi tutulduğunda yanmaya devam ettikleri, kendilerini söndüremedikleri bu nedenle de UL 94 standardının belirlediği sınıflandırmalara giremeyerek en kötü sonuçlara sahip oldukları tespit edildi. Bununla beraber $\alpha, \omega$ hidroksi alkil telekelik PDMS oligomeri (Tegomer ${ }^{\circledR}$ H-Si 2315) kullanılarak hazırlanan örnekler teste tabi tutulduğunda alevin çekilmesini takiben hemen alevin söndüğü ancak alevli olmayan damlama yaptığı görüldü.

Poliol (PPG 2000) esaslı poliüretan kaplamaların yüksek hızlarda yandığ (8-10 s) buna karşılık $\alpha, \omega$-hidroksi alkil telekelik PDMS oligomeri (Tegomer ${ }^{\circledR}$ H-Si 2315) esaslı poliüretan kaplamalarda alevin ilerlemediği tespit edildi. $\alpha, \omega$-hidroksi alkil telekelik PDMS oligomerinin (Tegomer ${ }^{\circledR} \mathrm{H}-\mathrm{Si} 2315$ ) poliüretan yapısına katılması ile elde edilen UL 94 standardına göre sinıflandırmaya bile giremeyen örneklerin en iyi sınıf olan V0 sınıfı değerlerine ulaştırılabilmesi ve yatay yanma hızları açısından elde edilen sonuçlar, çalışmamızın odağında bulunan ve en öncelikli çabamız olan poliüretan kaplamaların yanma davranışlarının iyileştirilmesi amacına başarı ile ulaşıldığının önemli delilleri olarak değerlendirilebilir.

Sonuç olarak başarı ile sentezlenen poliüretan kaplamalarda $\alpha, \omega$-hidroksi alkil telekelik PDMS oligomeri kullanımının en öncelikli performans kriteri olan yanma davranışının iyileştirilmesi parametresinde üstün bir başarı ortaya koyduğu ilgili standarta göre sınıflandırmaya bile giremeyen örneklerin en üst sınıfın performansına ulaştırıldığı tespit edildi.

Ayrica bir kaplamadan beklenen en temel özellikler olan yapışma kuvveti ve su yalıtım özellikleri açısından $\alpha, \omega$-hidroksi alkil telekelik PDMS oligomeri kullanılarak sentezlenen poliüretan kaplamaların poliol kullanılarak sentezlenen poliüretan kaplamalarla benzer özellikler sergilediği yani yanma davranışının iyileştirilmesi amacıyla poliüretan kaplamaların yapısına $\alpha, \omega$-hidroksi alkil telekelik PDMS oligomerinin dahil edilmesinin kaplama özellikleri açısından olumsuz bir sonuç doğurmayacağı tespit edildi.

Çalışma kapsamında gerçekleştirilen yöntem esas alınarak sentez reçetesinde zincir uzatıcı ve poliol veya $\alpha, \omega$-hidroksi alkil telekelik PDMS oligomerinin mol oranlarının istenilen oranlarda alınarak yumuşak ve sert segmentlerin oranının ayarlanabilmesi ile arzu edilen nitelikte mekanik özelliklere sahip poliüretan kaplamaların başarı ile hazırlanabileceği gerçeğine ulaşıldı. 


\section{Teşekkür}

Bu çalışmayı 2016/BAP/137 proje kodu ile destekleyen Yalova Üniversitesi Bilimsel Araştırma Projeleri Koordinatörlüğü Birimine teşekkür ederiz.

\section{Kaynakça}

Gooch, J. W. (2007). Encyclopedic Dictionary of Polymers. Springer

Grand, A. F. ve Wilkie, C. A. (2000). Fire Retardancy of Polymeric Materials. Marcel Dekker Inc.

Harper, C.A. (2000) Handbook of Building Materials for Fire Protection. McGraw-Hill.

Herman, F. M. (1964). Encyclopedia of Polymer Science and Technology. John Wiley and Sons.

Horrocks, A.R. ve Price, D. (2001). Fire Retardant Materials. Woodhead Publishing.

Kazama, H. Tezuka, Y. ve Imai, K. (1989). Synthesis of Polyurethane- Polysiloxane Block Copolymer Having Uniform-Size Polydimethylsiloxane) Segments. PolymerPlastics Technology and Engineering, 28(2), 109-121.

Kozakiewicz, J. (1996). Polysiloxaneurethanes new polymers for potential coating applications. Progress in Organic Coatings, 27, 123-131.

Kulshreshtha, A.K. ve Vasile, C. (2002). Handbook of Polymer Blends and Composites. Rapra Technology Limited.

Martin, E.A. (2010). A Dictionary of Science. Oxford University Press.

Nyilas, E. (1971). Polysiloxane-Polyurethane Block Copolymers. US Patent 3,562,352.

Parker, S. P. (2002). Mcgraw-Hill Dictionary of Scientific and Technical Terms. Mcgraw-Hill Education.

Pearce, E. (2012). Flame-Retardant Polymeric Materials. Springer Science \& Business Media.

Pişkin, E. (2000). Polimerler 2 Mühendislik Polimerleri. Pagyay Yayıncilık.

Tezuka, Y. Kazama, H. ve lmai, K. (1991). Environmentally induced Macromolecular Rearrangement on the Surface of Polyurethane-Polysiloxane Block Copolymers. Journal of the Chemical Society, Faraday Transactions., 87(1), 147-152.

Weil, E.D. ve Levchik, S.V. (2009). Flame retardants for plastics and textiles. Carl Hanser Verlag.

Yilgör, İ. ve McGrath, J. E. (1988). Polysiloxane containing copolymers: A survey of recent developments. Advances in Polymer Science Series, 86, 1-86.

Zhu, Q. Feng, S. ve Zhang, C. (2003). Synthesis and Thermal Properties of Polyurethane-Polysiloxane Crosslinked Polymer Networks. Journal of Applied Polymer Science, 90, 310-315. 